\title{
Duplication and expression patterns of CYCLOIDEA-like genes in Campanulaceae
}

\author{
Jingjing Tong ${ }^{1}$, Eric B. Knox ${ }^{2}$, Clifford W. Morden ${ }^{3}$, Nico Cellinese ${ }^{4}$, Fatima Mossolem ${ }^{1}$, Aarij S. Zubair ${ }^{1}$ and
}

Dianella G. Howarth ${ }^{1 *}$ (D)

\begin{abstract}
Background: CYCLOIDEA (CYC)-like transcription factors pattern floral symmetry in most angiosperms. In core eudicots, two duplications led to three clades of CYC-like genes: CYC1, CYC2, and CYC3, with orthologs of the CYC2 clade restricting expression dorsally in bilaterally symmetrical flowers. Limited data from CYC3 suggest that they also play a role in flower symmetry in some asterids. We examine the evolution of these genes in Campanulaceae, a group that contains broad transitions between radial and bilateral floral symmetry and $180^{\circ}$ resupination (turning upside-down by twisting pedicle).
\end{abstract}

Results: We identify here all three paralogous CYC-like clades across Campanulaceae. Similar to other core eudicots, we show that CamCYC2 duplicated near the time of the divergence of the bilaterally symmetrical and resupinate Lobelioideae. However, in non-resupinate, bilaterally symmetrical Cyphioideae, CamCYC2 appears to have been lost and CamCYC3 duplicated, suggesting a novel genetic basis for bilateral symmetry in Cyphioideae. We additionally, utilized qRT-PCR to examine the correlation between CYC-like gene expression and shifts in flower morphology in four species of Lobelioideae. As expected, CamCYC2 gene expression was dorsoventrally restricted in bilateral symmetrical flowers. However, because Lobelioideae have resupinate flowers, both CamCYC2A and CamCYC2B are highly expressed in the finally positioned ventral petal lobes, corresponding to the adaxial side of the flower relative to meristem orientation.

Conclusions: Our sequences across Campanulaceae of all three of these paralogous groups suggests that radially symmetrical Campanuloideae duplicated CYC1, Lobelioideae duplicated CYC2 and lost CYC3 early in their divergence, and that Cyphioideae lost CYC2 and duplicated CYC3. This suggests a dynamic pattern of duplication and loss of major floral patterning genes in this group and highlights the first case of a loss of CYC2 in a bilaterally symmetrical group. We illustrate here that CYC expression is conserved along the dorsoventral axis of the flower even as it turns upsidedown, suggesting that at least late CYC expression is not regulated by extrinsic factors such as gravity. We additionally show that while the pattern of dorsoventral expression of each paralog remains the same, CamCYC2A is more dominant in species with shorter relative finally positioned dorsal lobes, and CamCYC2B is more dominant in species with long dorsal lobes.

Keywords: Campanulaceae, CYCLOIDEA, Flower symmetry, Gene expression, Gene duplication, Lobelioideae, Cyphioideae, Campanuloideae

*Correspondence: howarthd@stjohns.edu

1 Department of Biological Sciences, St. John's University, Jamaica, NY, USA

Full list of author information is available at the end of the article

\section{Background}

\section{Campanulaceae diversity}

Campanulaceae, the bellflower family, are a large core eudicot group that encompasses roughly 2400 species in 84 genera [1]. They are found on six continents and original author(s) and the source, provide a link to the Creative Commons licence, and indicate if changes were made. The images or other third party material in this article are included in the article's Creative Commons licence, unless indicated otherwise in a credit line to the material. If material is not included in the article's Creative Commons licence and your intended use is not permitted by statutory regulation or exceeds the permitted use, you will need to obtain permission directly from the copyright holder. To view a copy of this licence, visit http://creativecommons.org/licenses/by/4.0/. The Creative Commons Public Domain Dedication waiver (http://creativeco mmons.org/publicdomain/zero/1.0/) applies to the data made available in this article, unless otherwise stated in a credit line to the data. 
many oceanic islands and are distributed from the tropics to the subarctic zones. There are at least three putative synapomorphic characters shared in Campanulaceae: laticifers, stamens attached to the disc of the ovary, and epigynous flowers [1]. The group is also recognized for its diversity in floral symmetry, resupination, and its pollination presentation mechanism.

The Campanulaceae are divided into five monophyletic subfamilies: Campanuloideae, Cyphioideae, Lobelioideae, Cyphocarpoideae, and Nemacladoideae [1]. Related groups to Campanulaceae are largely radially symmetrical, including the entirely radially symmetrical Rousseaceae. Campanuloideae have radially symmetrical flowers, while the other four clades have bilaterally symmetrical flowers $[1,2]$. Campanuloideae includes approximately 1050 species in 50 genera. They are distributed worldwide, especially in temperate areas of the Old World, with the major centers of diversity in the Mediterranean Basin and the Middle East [1-3]. The Lobelioideae encompass about 1200 species in 29 genera [1]. They are also distributed nearly worldwide, with an origin in southern Africa [4], and a center of diversity in the New World tropics with a predominantly South American clade, "CBS (named for Centropogon, Burmeistera, and Siphocampylus)," containing roughly half the extant species $[1,5,6]$. Most species in Lobelioideae have resupinate (rotated $180^{\circ}$ on the dorsoventral axis), bilaterally symmetrical flowers, connate (fused) stamens that form a staminal column tipped with an anther tube that releases pollen to the interior, and styles with brush hairs. The Lobelioideae exhibit a large diversification in growth-form, from small, herbaceous plants, to shrubs, to woody-rosette giant lobelias [7-10]. The Cyphioideae include $64+$ species that are restricted to tropical and southern Africa. Cyphioideae and Campanuloideae are sister-groups [11], and share a simple pollen deposition mechanism [2]. The other three subfamilies (Lobelioideae, Cyphocarpoideae, and Nemacladoideae) weakly group together as a separate clade $[2,7,11-13]$ The two smallest subfamilies, Cyphocarpoideae and Nemacladoideae, with smaller ranges and 3 and 25 species respectively [1], were not sampled in this study.

\section{Flower architecture and morphology}

The symmetry of flowers is associated with their pollination, speciation, and diversification [14-16]. Floral symmetry can be classified into two main types: radially symmetrical (actinomorphic; polysymmetric), in which the flower has two or more central axes of symmetry; and bilaterally symmetrical (zygomorphic, monosymmetric), which have a flower with only one central axis of symmetry [14, 17]. Most asterid species have an additional complexity of partial corolla fusion, forming a sympetalous corolla tube proximally, and distinct petal lobes distally. Generally, bilaterally symmetrical flowers have floral organs of three different sizes or shapes (especially in the corolla lobes): dorsal (adaxial), lateral, and ventral (abaxial). In core eudicots, bilaterally symmetrical flowers most frequently have a corolla lobe arrangement of 2 dorsal lobes, 2 lateral lobes, and 1 ventral lobe $(2+3$ form $)$. Other common forms include $(4+1)$ and $(0+5)$, with all of these types including a central ventral lobe pointed downward while the other four lobes shift in location [17].

The ancestral flower symmetry of Campanulaceae remains equivocal given that Campanulaceae is divided into a bilaterally symmetrical clade (Lobelioideae, Cyphocarpoideae, and Nemacladoideae) and a clade with both bilaterally (Cyphoideae) and radially (Campanuloideae) symmetric lineages. Ancestral state reconstruction suggests the ancestor may have had bilaterally symmetrical flowers, with a reversal to radially symmetrical flowers in the Campanuloideae (Fig. 1A-D), [2], but related outgroups are nearly all radially symmetrical and the independent evolution of zygomorphy is equally plausible. In the other major clade, Lobelioideae, almost all species have resupinate flowers with $(2+3)$ or $(0+5)$ final floral displays (Figs. 1E-I, 2), except in Monopsis and two species of Downingia, in which flowers are not resupinate (with reversal to resupination in $M$. decipiens) $[1,18]$. The remaining three subfamilies have non-resupinated flowers, with Cyphioideae (Fig. 1J, K) and Nemacladoideae having a $(3+2)$ form, and Cyphocarpoideae having a $(1+4)$ form $[1,2]$. The shift in this family in both symmetry and resupination provide novel variation to examine how genes affect plant organ orientation and twisting of structures (Fig. 2).

Resupination in Lobelioideae occurs via the twisting of the pedicle after floral buds have formed [19]. Here we follow the terminology of Bukhari et al. [20] and use adaxial/abaxial to refer to the floral meristem orientation of the floral bud at developmental initiation, relative to the stem and subtending bract. We use dorsal/ventral to refer to the orientation of the final floral display (Fig. 2). Therefore, in resupinate Lobelioideae species, their abaxial region is in the dorsal position at anthesis.

\section{Genetic basis of floral symmetry}

CYCLOIDEA (CYC) was the first characterized member of the floral symmetry gene regulatory network with a strong dorsal phenotypic effect, especially in the corolla and androecium [21-26]. In Antirrhinum majus (snapdragon), $C Y C$-like genes are necessary to establish the dorsoventral axis in bilaterally symmetrical flowers [21]. CYC genes are members of the TCP gene family which exhibit high levels of sequence conservation in their 

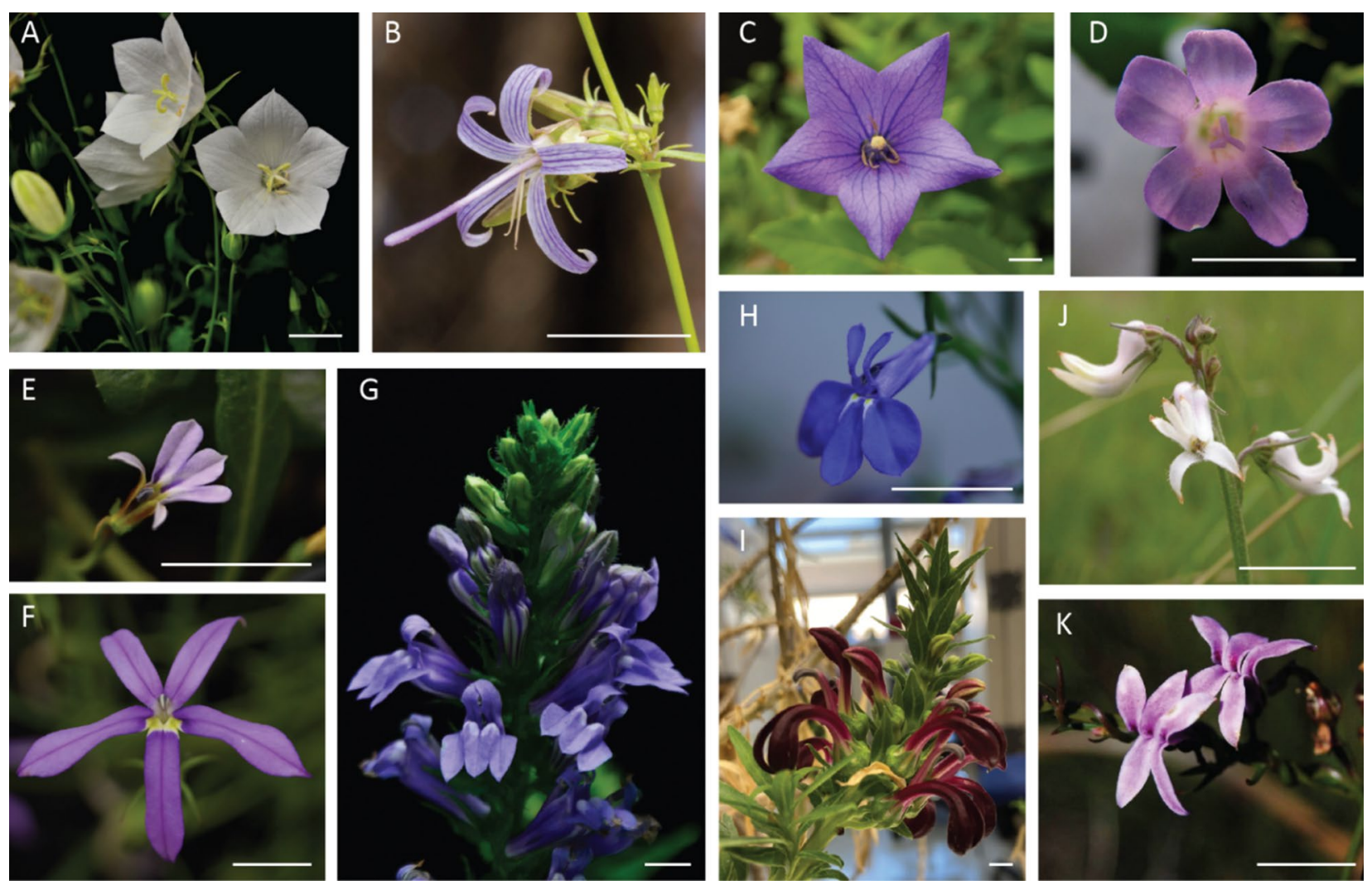

Fig. 1 Campanulaceae species. A-D Campanuloideae species, have radially symmetrical flowers. E-I Nearly all Lobelioideae species, have different forms of resupinate, bilaterally symmetrical flowers. $\mathbf{J}$ and $\mathbf{K}$ Cyphioideae species, have bilaterally symmetrical flowers that are not resupinate. $\mathbf{A}$ Campanula carpatica, B Asyneuma prenanthoides*, C Platycodon grandiflorus, D Campanula portenschlagiana, E Lobelia anceps, $\mathbf{F}$ Lithotoma axillaris, G Lobelia siphilitica, H Lobelia erinus, I Lobelia polyphylla, J Cyphia longifolia**, K Cyphia longipetala**. *Photo right reserved to Marlin Harm. ${ }^{* *}$ Photo right reserved to Eric Knox. Other photos taken by Jingjing Tong

TCP and R domains [27]. CYC, together with its paralog DICHOTOMA $(D I C H)$, co-express in the dorsal domain of the floral meristem from initiation and cause a reduction in growth of the corolla and stamens [28]. Cyc-dich double mutants in A. majus form radially symmetrical, ventralized flowers. Evidence from numerous comparative studies across flowering plants has shown that the duplication of $C Y C$-like genes is highly correlative with the development of floral morphology in bilaterally symmetrical flowers [29-38]. Duplications or changes in the location or level of gene expression of $C Y C$-like genes is highly associated with evolutionary shifts between radially symmetrical and bilaterally symmetrical flowers [39, 40].

Previous research has shown that two duplication events near the time of the diversification of the core eudicots produced three clades of $C Y C$-like genes: $C Y C 1$, $C Y C 2$ and $C Y C 3$ [41]. Originally characterized $C Y C$ and $D I C H$ from $A$. majus are members of the $C Y C 2$ clade and is widely involved in controlling bilateral symmetry across core eudicots $[39,41]$. There are two or more paralogs of $C Y C 2$ genes in nearly all characterized bilaterally symmetrical clades of core eudicots. In Asteraceae and Dipsacaceae, some clades have capitate inflorescences, which contain both radially and bilaterally symmetrical flowers. In these groups, there are multiple copies of $C Y C 2$ genes, and they appear to be differentially expressed across the flowers of the inflorescence [29, 31$38,40]$. Additionally, the dorsoventral gradient of $C Y C 2$ expression positively correlates with the level of bilateral symmetry [40]. In Asteraceae, the over-expression of $C Y C 2$ genes can result in radially symmetrical disc flowers shifting to be more bilaterally symmetric [37].

The two additional paralogs of $C Y C$-like genes have received less attention, although evidence indicates that they are also involved in inflorescence and/or floral patterning. The $C Y C 1$ genes have not been shown to be directly involved in floral development, but $C Y C 1$ genes may be responsible for plant or inflorescence branching architecture in Arabidopsis, Populus, and Asteraceae [37, 42-44]. The function of CYC3 genes are still unclear in floral development [44]; however, based 


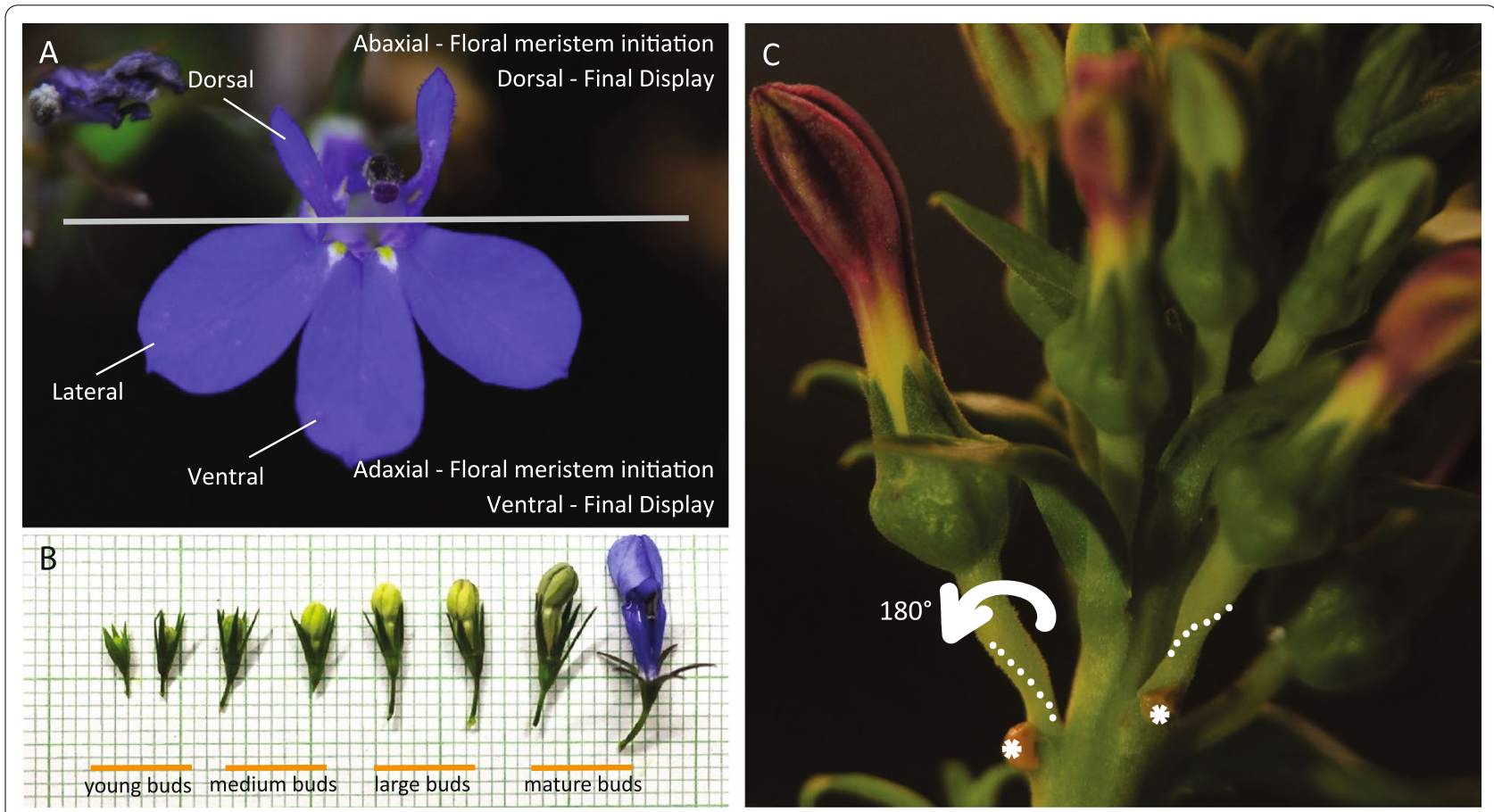

Fig. 2 Lobelioideae flowers. A Lobelia erinus flower, B L. erinus floral buds in different stages. C Lobelia polyphylla large flower bud at the late development stage with removed bract. Asterisk marks location of latex exuding from removal of abaxial bract. Lobelioideae have resupinate flowers with the entire bud turning 180-degrees during development, resulting in the adaxial floral meristem region being the ventral region, and the abaxial floral meristem region being the dorsal region when the flower is mature. During floral bud growth, pedicels turn around at a relatively early stage of bud development and are completely turned 180-degrees upside-down by later stages of bud development. White dots show the location of the twist in the pedicels. Photos taken by Jingjing Tong

on gene expression data from Dipsacales and Asterales, $C Y C 3$ genes may play a role in symmetry, at least in the campanulid (asterid II) clade [40, 45].

Given the resupinate flowers of the Lobelioideae, as well as the shifts in symmetry in the Campanulaceae sensu lato, we aimed to examine the evolutionary history of the Campanulaceae $C Y C$-like (CamCYC-like) genes. We sampled CamCYC from Campanuloideae, Lobelioideae, and Cyphioideae species (Table 1) and compared them to molecular phylogenetic results for Campanulaceae $[3,7,46]$. The main aims in this study were to pinpoint the duplication events of CamCYC -like genes across Campanulaceae and use qRT-PCR to investigate the expression of CamCYC2 genes in Lobelioideae species with resupinate, bilaterally symmetrical flowers. We examined expression in four species with different forms of bilateral symmetry and relative lobe lengths. CamCYC2A and $C a m C Y C 2 B$ are highly expressed in the finally positioned ventral lobes (the adaxial side of the flower), suggesting conservation of dorsal identity in upside-down flowers. Additionally, individual copies of $\mathrm{CamCYC} 2$ genes show different expression levels in different lobes, suggesting possible subfunctionalization between these copies.

\section{Results}

CamCYC1, CamCYC2, and CamCYC3 from Campanulaceae Sequencing the TCP through $\mathrm{R}$ domains, we isolated CamCYC1 from 83 Lobelioideae species, eight Campanuloideae species, and seven Cyphioideae species; CamCYC2 from 90 Lobelioideae species and four Campanuloideae species; and CamCYC3 from five Lobelioideae species, three Campanuloideae species, and eight Cyphioideae species. There were no CamCYC2 gene sequences isolated from Cyphioideae. The tree topologies across the CamCYC1, CamCYC2, and CamCYC3 clades were generally congruent with the estimated species phylogenies in these groups, especially in the best-sampled Lobelioideae. All three subfamilies were monophyletic and were consistent with a sister group relationship between Campanuloideae and Cyphioideae (Figs. 3, 4, and 5).

The CamCYC1 sequence matrix was 492 bps long with 140 sequences, which included 12 sequences from Campanuloideae and nine sequences from Cyphioideae. Using midpoint rooting, Campanuloideae and Cyphioideae grouped in one clade, sister to the remaining 119 sequences, all isolated from 83 Lobelioideae species (Fig. 3). Our data support a duplication in CamCYC1 
Table 1 Campanulaceae species used in this study, including Genbank numbers for each sequenced gene/allele in each CYC gene clade

\begin{tabular}{|c|c|c|c|c|c|c|c|}
\hline Clade & Label & Genus & Species & CYC1 & $C Y C 2 B$ & $C Y C 2 A$ & $\mathrm{CYC3}$ \\
\hline Campanuloideae & $\mathrm{JCO02}(\mathrm{JT})$ & Campanula & carpatica & OM262907 & OM263037 & & OM263196 \\
\hline Campanuloideae & $\mathrm{JC008(JT)}$ & Campanula & cochleariifolia & $\begin{array}{l}\text { OM262908 } \\
\text { OM262909 }\end{array}$ & & & \\
\hline Campanuloideae & 3195(NC) & Campanula & drabifolia & & & & OM263198 \\
\hline Campanuloideae & JC006(JT) & Campanula & glomerata & OM262910 & OM263038 & & \\
\hline Campanuloideae & CP011(JT) & Platycodon & grandiflorus & OM262918 & OM263039 & & \\
\hline Campanuloideae & CJ009(JT) & Jasione & montana & OM262915 & & & \\
\hline Campanuloideae & CJ001(JT) & Campanula & persicifolia & $\begin{array}{l}\text { OM262911 } \\
\text { OM262912 }\end{array}$ & & & \\
\hline Campanuloideae & $\mathrm{JCO07}(\mathrm{JT})$ & Campanula & portenschlagiana & $\begin{array}{l}\text { OM262913 } \\
\text { OM262914 }\end{array}$ & & & OM263197 \\
\hline Campanuloideae & CP012(JT) & Phyteuma & scheuchzeri & $\begin{array}{l}\text { OM262916 } \\
\text { OM262917 }\end{array}$ & OM263036 & & \\
\hline Cyphioideae & K4686 & Cyphia & comptonii & OM262919 & & & $\begin{array}{l}\text { OM263203 } \\
\text { OM263209 }\end{array}$ \\
\hline Cyphioideae & P5532 & Cyphia & digitata & OM262920 & & & $\begin{array}{l}\text { OM263199 } \\
\text { OM263200 }\end{array}$ \\
\hline Cyphioideae & K4725 & Cyphia & eckloniana & OM262921 & & & OM263207 \\
\hline Cyphioideae & K2340 & Cyphia & lasiandra & OM262922 & & & OM263210 \\
\hline Cyphioideae & K4734 & Cyphia & longipetala & OM262924 & & & $\begin{array}{l}\text { OM263201 } \\
\text { OM263204 }\end{array}$ \\
\hline Cyphioideae & P5461 & Cyphia & rogersii & OM262925 & & & OM263208 \\
\hline Cyphioideae & K4831 & Cyphia & smutsii & & & & OM263211 \\
\hline Cyphioideae & P5555 & Cyphia & sp. nov & OM262923 & & & $\begin{array}{l}\text { OM263202 } \\
\text { OM263205 }\end{array}$ \\
\hline Cyphioideae & K4726 & Cyphia & volubilis & OM262926 & & & OM263212 \\
\hline Cyphioideae & K4675 & Cyphia & zeyheriana & OM262927 & & & OM263206 \\
\hline \multicolumn{8}{|l|}{ Lobelioideae } \\
\hline Genistoid E & K4216 & Lobelia & baumannii & OM262958 & OM263140 & OM263055 & \\
\hline Genistoid E & K4942 & Lobelia & comptonii & OM262965 & & OM263061 & \\
\hline Genistoid E & K4773 & Lobelia & dasyphylla & OM262969 & & OM263063 & \\
\hline Genistoid E & K4314 & Lobelia & goetzei & OM262973 & OM263154 & OM263066 & \\
\hline Genistoid E & K3316 & Lobelia & hartlaubii & OM262976 & OM263114 & OM263067 & \\
\hline Genistoid E & K4814 & Lobelia & malowensis & OM262987 & OM263159 & OM263070 & \\
\hline Genistoid E & K4609 & Lobelia & patula & OM262991 & OM263075 & OM263076 & \\
\hline Genistoid E & P5475 & Lobelia & pteropoda & OM262992 & & OM263079 & \\
\hline Genistoid E & K4634 & Lobelia & tomentosa & OM263010 & OM263177 & & \\
\hline Genistoid E & K4654 & Lobelia & vanreenensis & OM263014 & & OM263094 & \\
\hline Impares F & K5251 & Lobelia & cleistogamoides & $\begin{array}{l}\text { OM262962 } \\
\text { OM262963 }\end{array}$ & & & OM263215 \\
\hline Impares F & K5245A & Lobelia & heterophylla & OM262964 & & & $\begin{array}{l}\text { OM263213 } \\
\text { OM263214 }\end{array}$ \\
\hline Impares F & K5210 & Colensoa & physaloides & $\begin{array}{l}\text { OM262935 } \\
\text { OM262936 }\end{array}$ & & & OM263218 \\
\hline Impares F & K5242 & Lobelia & rarifolia & $\begin{array}{l}\text { OM262994 } \\
\text { OM262995 }\end{array}$ & & OM263080 & \\
\hline Impares F & K5259 & Lobelia & rhombifolia & $\begin{array}{l}\text { OM262996 } \\
\text { OM262997 }\end{array}$ & & OM263081 & \\
\hline Impares F & K5253 & Lobelia & rhytidosperma & OM262998 & & OM263084 & \\
\hline Impares F & K5279 & Lobelia & simplicicaulis & $\begin{array}{l}\text { OM263000 } \\
\text { OM263002 }\end{array}$ & OM263172 & OM263087 & \\
\hline Impares F & K5234 & Lobelia & tenuior & OM263007 & & & OM263216 \\
\hline
\end{tabular}


Table 1 (continued)

\begin{tabular}{|c|c|c|c|c|c|c|c|}
\hline Clade & Label & Genus & Species & CYC1 & $C Y C 2 B$ & $C Y C 2 A$ & $\mathrm{CYC3}$ \\
\hline Impares F & A10185 & Lobelia & trigonocaulis & OM263011 & & OM263091 & OM263217 \\
\hline Impares F & K5252 & Lobelia & winifrediae & & OM263082 & OM263083 & \\
\hline Monopsis G & K4628 & Monopsis & alba & OM263023 & OM263108 & OM263107 & \\
\hline Monopsis G & K4790 & Monopsis & debilis & OM263025 & & & \\
\hline Monopsis G & K4646 & Monopsis & decipiens & OM263024 & & OM263104 & \\
\hline Monopsis G & K5116 & Monopsis & flava & OM263026 & & & \\
\hline Monopsis G & K4402 & Monopsis & stellarioides & OM263027 & OM263109 & & \\
\hline Monopsis G & P5246 & Monopsis & unidentata & OM263028 & & $\begin{array}{l}\text { OM263105 } \\
\text { OM263106 }\end{array}$ & \\
\hline Broom H & P5621 & Lobelia & lasiantha & OM262978 & & & \\
\hline Broom H & K4599 & Lobelia & linearis & OM262980 & & & \\
\hline Grammatotheca I & K4642 & Lobelia & thermalis & & & OM263089 & \\
\hline Erinoid L & K4951 & Lobelia & boivinii & & & OM263057 & \\
\hline Erinoid L & K3475 & Lobelia & cymbalarioides & OM262968 & & OM263062 & \\
\hline Erinoid L & JL002(JT) & Lobelia & erinus & OM262970 & OM263152 & OM263065 & \\
\hline Erinoid L & K4964 & Lobelia & inconspicua & & & OM263068 & \\
\hline Erinoid L & K3401 & Lobelia & minutula & OM262988 & & OM263073 & \\
\hline Erinoid L & K4841 & Lobelia & wilmsiana & OM263017 & & OM263090 & \\
\hline Wimmerella M & K5276 & Lobelia & anceps & & OM263137 & & \\
\hline Wimmerella M & K4685 & Wimmerella & bifida & OM263035 & OM263192 & & \\
\hline Wimmerella M & K4594 & Wimmerella & hederacea & OM263033 & OM263193 & OM263097 & \\
\hline Wimmerella M & K4545 & Wimmerella & pygmaea & OM263034 & OM263194 & OM263101 & \\
\hline Wimmerella M & K5104 & Wimmerella & secunda & & OM263195 & OM263102 & \\
\hline Mezlerioid3 N & K5182 & Lobelia & jasionoides & OM262977 & OM263155 & & \\
\hline Mezlerioid3 N & K4566 & Lobelia & laurentioides & OM262979 & OM263157 & & \\
\hline Mezlerioid3 N & K4589 & Lobelia & muscoides & OM262989 & OM263161 & & \\
\hline Solenopsis O & $\mathrm{GrO4/1}$ & Lobelia & urens & & OM263180 & OM263092 & \\
\hline W North America P & K4663 & Downingia & bicornuta & OM262948 & & & \\
\hline W North America P & UCBG770105 & Palmerella & debilis & OM262946 & & OM263098 & \\
\hline W North America P & K4667 & Porterella & carnosula & OM262947 & OM263115 & OM263099 & \\
\hline Diastatea Q & Wo8295 & Diastatea & micrantha & & $\begin{array}{l}\text { OM263110 } \\
\text { OM263111 }\end{array}$ & $\mathrm{OM} 263050$ & \\
\hline E North America R & Jl007(JT) & Lobelia & cardinalis & & OM263146 & OM263060 & \\
\hline E North America R & K5282 & Lobelia & dortmanna & & OM263151 & & \\
\hline E North America R & K2408 & Lobelia & fenestralis & OM262949 & OM263112 & & \\
\hline E North America R & K5092 & Lobelia & puberula & & OM263113 & & \\
\hline E North America R & JL003(JT) & Lobelia & siphilitica & & OM263173 & OM263088 & \\
\hline South America S & Ra s.n.2 & Burmeistera & crispiloba & $\begin{array}{l}\text { OM262930 } \\
\text { OM262931 }\end{array}$ & & OM263042 & \\
\hline South America S & Lu15078 & Centropogon & comosus & $\begin{array}{l}\text { OM262932 } \\
\text { OM262933 }\end{array}$ & OM263119 & OM263043 & \\
\hline South America S & JL005(JT) & Lobelia & bridgesii & $\begin{array}{l}\text { OM262960 } \\
\text { OM262961 }\end{array}$ & OM263143 & OM263058 & \\
\hline South America S & JL006(JT) & Lobelia & polyphylla & & $\begin{array}{l}\text { OM263164 } \\
\text { OM263165 }\end{array}$ & OM263078 & \\
\hline South America S & JL004(JT) & Lobelia & tupa & $\begin{array}{l}\text { OM263012 } \\
\text { OM263013 }\end{array}$ & $\begin{array}{l}\text { OM263178 } \\
\text { OM263179 }\end{array}$ & & \\
\hline Australasia T & RBGK2368 & Hypsela & Reniformis & OM262942 & OM263129 & & \\
\hline Australasia T & A9820 & Isotoma & gulliveri & $\begin{array}{l}\text { OM262944 } \\
\text { OM262945 }\end{array}$ & OM263132 & & \\
\hline Australasia T & K5237 & Isotoma & hypocrateriformis & OM262943 & OM263133 & OM263134 & \\
\hline
\end{tabular}


Table 1 (continued)

\begin{tabular}{|c|c|c|c|c|c|c|c|}
\hline Clade & Label & Genus & Species & CYC1 & $C Y C 2 B$ & $C Y C 2 A$ & $\mathrm{CYC3}$ \\
\hline Australasia T & LI010(JT) & Lithotoma & axillaris & & OM263130 & OM263051 & \\
\hline Australasia T & W5440 & Lithotoma & petraea & OM262954 & OM263131 & OM263052 & \\
\hline Australasia T & K5024A & Lobelia & macrodon & OM262985 & OM263072 & OM263071 & \\
\hline Australasia T & Ck2245 & Lobelia & pratioides & OM262993 & OM263166 & OM263077 & \\
\hline Australasia T & K5027 & Lobelia & roughii & OM262999 & OM263167 & OM263085 & \\
\hline Australasia T & K2369 & Pratia & arenaria & $\begin{array}{l}\text { OM262950 } \\
\text { OM262951 }\end{array}$ & OM263187 & & \\
\hline Australasia T & W5265 & Pratia & gelida & OM262952 & OM263188 & & \\
\hline Australasia T & A5357 & Pratia & pedunculata & OM262953 & OM263189 & OM263100 & \\
\hline Giants U & NTBG970260 & Apetahia & longistigmata & $\begin{array}{l}\text { OM262928 } \\
\text { OM262929 }\end{array}$ & $\begin{array}{l}\text { OM263116 } \\
\text { OM263117 }\end{array}$ & & \\
\hline Giants U & $4561(\mathrm{CM})$ & Brighamia & insignis & $\begin{array}{l}\text { OM262905 } \\
\text { OM262906 }\end{array}$ & OM263118 & $\begin{array}{l}\text { OM263040 } \\
\text { OM263041 }\end{array}$ & \\
\hline Giants U & 6799(CM) & Clermontia & micrantha & & OM263120 & OM263044 & \\
\hline Giants U & 7011 (CM) & Clermontia & persicifolia & OM262934 & OM263121 & OM263045 & \\
\hline Giants U & 1754(CM) & Cyanea & acuminata & $\begin{array}{l}\text { OM262937 } \\
\text { OM262938 }\end{array}$ & OM263122 & OM263046 & \\
\hline Giants U & K2375 & Cyanea & leptostegia & $\begin{array}{l}\text { OM262939 } \\
\text { OM262940 }\end{array}$ & & & \\
\hline Giants U & 2452(CM) & Cyanea & superba & OM262941 & $\begin{array}{l}\text { OM263123 } \\
\text { OM263124 }\end{array}$ & & \\
\hline Giants U & $5416(C M)$ & Delissea & rhytidosperma & $\begin{array}{l}\text { OM262896 } \\
\text { OM262897 } \\
\text { OM262903 } \\
\text { OM262904 }\end{array}$ & $\begin{array}{l}\text { OM263125 } \\
\text { OM263126 }\end{array}$ & $\begin{array}{l}\text { OM263047 } \\
\text { OM263048 }\end{array}$ & \\
\hline Giants U & 3835(CM) & Delissea & subcordata & $\begin{array}{l}\text { OM262901 } \\
\text { OM262902 }\end{array}$ & $\begin{array}{l}\text { OM263127 } \\
\text { OM263128 }\end{array}$ & OM263049 & \\
\hline Giants U & K706 & Lobelia & aberdarica & $\begin{array}{l}\text { OM262955 } \\
\text { OM262956 }\end{array}$ & $\begin{array}{l}\text { OM263135 } \\
\text { OM263136 }\end{array}$ & OM263053 & \\
\hline Giants U & K731 & Lobelia & bambuseti & & $\begin{array}{l}\text { OM263138 } \\
\text { OM263139 }\end{array}$ & OM263054 & \\
\hline Giants U & K220 & Lobelia & bequaertii & $\begin{array}{l}\text { OM262957 } \\
\text { OM262959 }\end{array}$ & $\begin{array}{l}\text { OM263141 } \\
\text { OM263142 }\end{array}$ & OM263056 & \\
\hline Giants U & K802 & Lobelia & burttii & & $\begin{array}{l}\text { OM263144 } \\
\text { OM263145 }\end{array}$ & OM263059 & \\
\hline Giants U & M2085 & Lobelia & columnaris & $\begin{array}{l}\text { OM262966 } \\
\text { OM262967 }\end{array}$ & $\begin{array}{l}\text { OM263147 } \\
\text { OM263148 }\end{array}$ & & \\
\hline Giants U & K2353 & Lobelia & doniana & OM262900 & $\begin{array}{l}\text { OM263149 } \\
\text { OM263150 }\end{array}$ & OM263064 & \\
\hline Giants U & K118 & Lobelia & giberroa & $\begin{array}{l}\text { OM262971 } \\
\text { OM262972 }\end{array}$ & OM263153 & & \\
\hline Giants U & K698 & Lobelia & gregoriana & $\begin{array}{l}\text { OM262974 } \\
\text { OM262975 }\end{array}$ & & & \\
\hline Giants U & K2381 & Lobelia & kauaensis & $\begin{array}{l}\text { OM262898 } \\
\text { OM262899 }\end{array}$ & OM263156 & & \\
\hline Giants U & K3522 & Lobelia & longisepala & OM262981 & & $\begin{array}{l}\text { OM263069 } \\
\text { OM263096 }\end{array}$ & \\
\hline Giants U & K623 & Lobelia & lukwangulensis & $\begin{array}{l}\text { OM262982 } \\
\text { OM262983 } \\
\text { OM262984 }\end{array}$ & OM263158 & OM263093 & \\
\hline Giants U & K426 & Lobelia & mildbraedii & & OM263160 & & \\
\hline Giants U & K619 & Lobelia & morogoroensis & OM262986 & & OM263074 & \\
\hline Giants U & NTBG910521 & Lobelia & niihauensis & OM262990 & OM263162 & & \\
\hline Giants U & $7162(\mathrm{CM})$ & Lobelia & oahuensis & & OM263163 & & \\
\hline
\end{tabular}


Table 1 (continued)

\begin{tabular}{|c|c|c|c|c|c|c|c|}
\hline Clade & Label & Genus & Species & CYC1 & $C Y C 2 B$ & $C Y C 2 A$ & $\mathrm{CYC3}$ \\
\hline Giants U & K610 & Lobelia & sancta & OM263001 & $\begin{array}{l}\text { OM263168 } \\
\text { OM263169 }\end{array}$ & OM263086 & \\
\hline Giants U & RBGK5627 & Lobelia & sessilifolia & & $\begin{array}{l}\text { OM263170 } \\
\text { OM263171 }\end{array}$ & & \\
\hline Giants U & $\mathrm{K} 120$ & Lobelia & stuhlmannii & $\begin{array}{l}\text { OM263003 } \\
\text { OM263004 }\end{array}$ & OM263174 & & \\
\hline Giants U & K689 & Lobelia & telekii & $\begin{array}{l}\text { OM263005 } \\
\text { OM263006 }\end{array}$ & & & \\
\hline Giants U & K876 & Lobelia & thuliniana & $\begin{array}{l}\text { OM263008 } \\
\text { OM263009 }\end{array}$ & $\begin{array}{l}\text { OM263175 } \\
\text { OM263176 }\end{array}$ & & \\
\hline Giants U & 4097(CM) & Lobelia & villosa & $\begin{array}{l}\text { OM263015 } \\
\text { OM263015 } \\
\text { OM263022 }\end{array}$ & $\begin{array}{l}\text { OM263181 } \\
\text { OM263182 }\end{array}$ & OM263095 & \\
\hline Giants U & K262 & Lobelia & wollastonii & $\begin{array}{l}\text { OM263018 } \\
\text { OM263019 }\end{array}$ & $\begin{array}{l}\text { OM263183 } \\
\text { OM263184 }\end{array}$ & & \\
\hline Giants U & K2379 & Lobelia & yuccoides & $\begin{array}{l}\text { OM263020 } \\
\text { OM263021 }\end{array}$ & $\begin{array}{l}\text { OM263185 } \\
\text { OM263186 }\end{array}$ & & \\
\hline Giants U & 4887(CM) & Trematolobelia & kauaiensis & $\begin{array}{l}\text { OM263029 } \\
\text { OM263031 }\end{array}$ & & & \\
\hline Giants U & 4764(CM) & Trematolobelia & macrostachys & $\begin{array}{l}\text { OM263030 } \\
\text { OM263032 }\end{array}$ & $\begin{array}{l}\text { OM263190 } \\
\text { OM263191 }\end{array}$ & OM263103 & \\
\hline
\end{tabular}

Included a total of 132 DNA samples, from 128 species, including 9 Cyphioideae species, 9 Campanuloideae species, and 110 Lobelioideae species (JT = Jingjing Tong, $\mathrm{NC}=$ Nico Cellinese, $\mathrm{CM}=$ Clifford Morden, all other samples provided by Eric Knox) $[75,76]$

within the Campanuloideae that is not shared with the other subfamilies (ML bootstrap $=100$ ), with Campanula cochlearifolia, C. persicifolia, C. portenschlagiana, and Phyteuma scheuchzeri occurring in both clades. Cyphioideae CamCYC1 sequences form a single clade, although multiple CamCYC1 gene sequences were isolated from most Cyphioideae samples, likely due to allelic diversity.

Lobelioideae CamCYC1 formed a single clade with no broad duplication detected across Lobelioideae. Species distribution in Lobelioideae CamCYC1 subclades are congruent with previously published Lobelioideae phylogenetic relationships [7, 10, 46, 47]. Clade names and letter designations used are from [7, 10, 46, 47] and Knox (unpublished data), with Genistoid (E) and Impares (F) subclades forming a clade sister to the remaining samples. The Impares (F) subclade appears to have duplicated CamCYC1 (ML bootstrap=92) with 5 out of 10 sampled species (Lobelia cleistogamoides, L. simplicicaulis, L. rhombifolia, L. rarifolia, and Colensoa physaloides) yielding two highly differentiated copies. The U subclade, often called the giant lobelias, in some cases yield three highly differentiated sequence copies. The duplicated copies in the U2-A and U2-B subclades are possibly a result of this group being ancient tetraploids [48, 49]. There is no obvious explanation for the copies that comprise the U1 subclade, which is weakly embedded in a clade with members of the $P, R, S$, and $T$ subclades.
The CamCYC2 matrix was 363 bps long with 160 sequences, which included 156 sequences from Lobelioideae and only four sequences isolated from Campanuloideae (Fig. 4). No CamCYC2 sequences were obtained from any Cyphioideae species despite targeted amplification. In the CamCYC2 gene tree (Fig. 4), sequences from Lobelioideae species formed two clades, both of which were broadly congruent with the hypothesized species relationships: $\operatorname{CamCYC2A}(\mathrm{ML}$ bootstrap $=92)$ and $C a m C Y C 2 B$ (ML bootstrap $=90)$. Species relationships in both Lobelioideae CamCYC2 clades shared a similar pattern and also corresponded with the Cam$C Y C 1$ tree. In the CamCYC2 tree, sequences from 43 Lobelioideae species were found in both $\mathrm{CamCYC2A}$ and $C a m C Y C 2 B$ clades. There were separate duplications into two $\mathrm{U}$ subclades in each of the CamCYC2 paralogs. Our data indicate that $\mathrm{CamCYC2}$ genes have duplicated in the Lobelioideae, a duplication that does not appear to be shared with the CamCYC2-like genes isolated from Campanuloideae.

The CamCYC3 gene tree included species from all three sampled subfamilies (Fig. 5). The CamCYC3 matrix was 329 bps long with 23 sequences, including three sequences from Campanuloideae, 14 sequences from Cyphioideae, and six sequences from Lobelioideae. Fewer CamCYC3 sequences were recovered compared to the other CamCYC genes. The three Campanuloideae sequences formed a clade. Sequences from Cyphioideae 


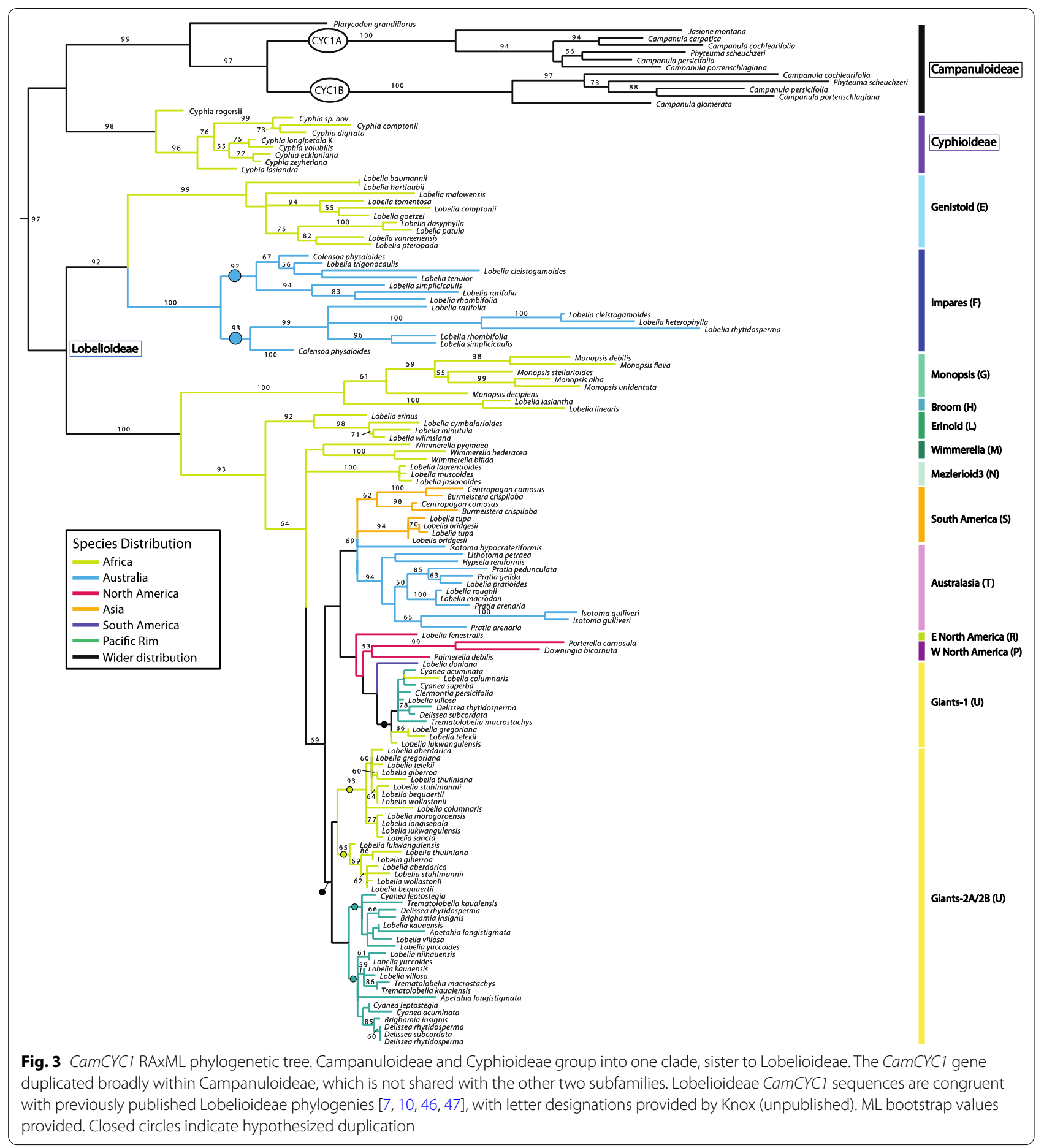

(See figure on next page.)

Fig. 4 Cam CYC2 RAxML phylogenetic tree. The CamCYC2 tree only includes sequences isolated from Lobelioideae and Campanuloideae, with no CamCYC2 genes found in Cyphioideae. In Lobelioideae there is a clear duplication across the entire clade, which is not shared with Campanuloideae. The species relationship patterns are congruent between the two Lobelioideae subclades. The $U$ clade includes multiple duplicate lineages in both CamCYC2 paralogs. ML bootstrap values provided. Closed circles indicate hypothesized duplication 


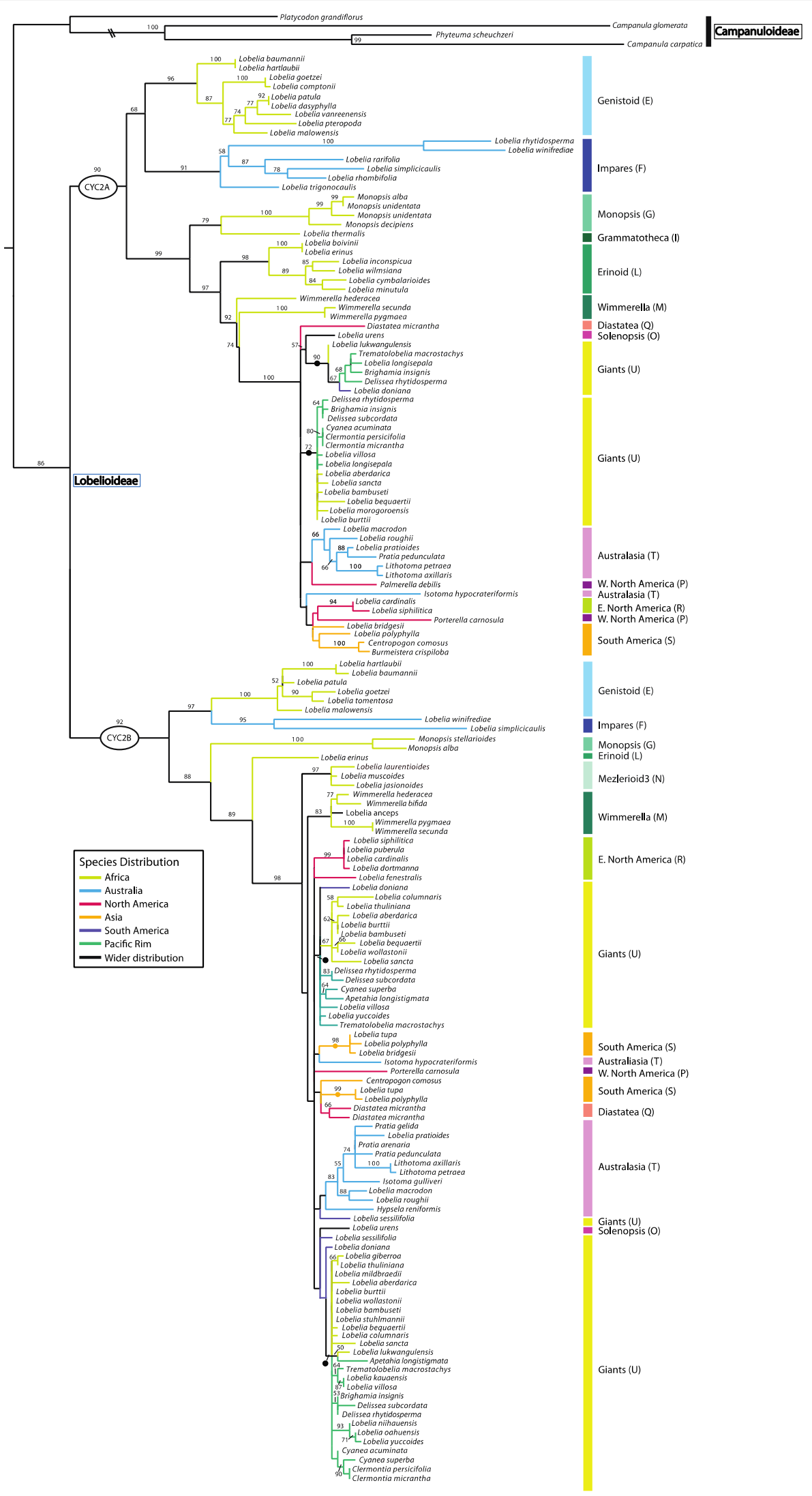

Fig. 4 (See legend on previous page.) 


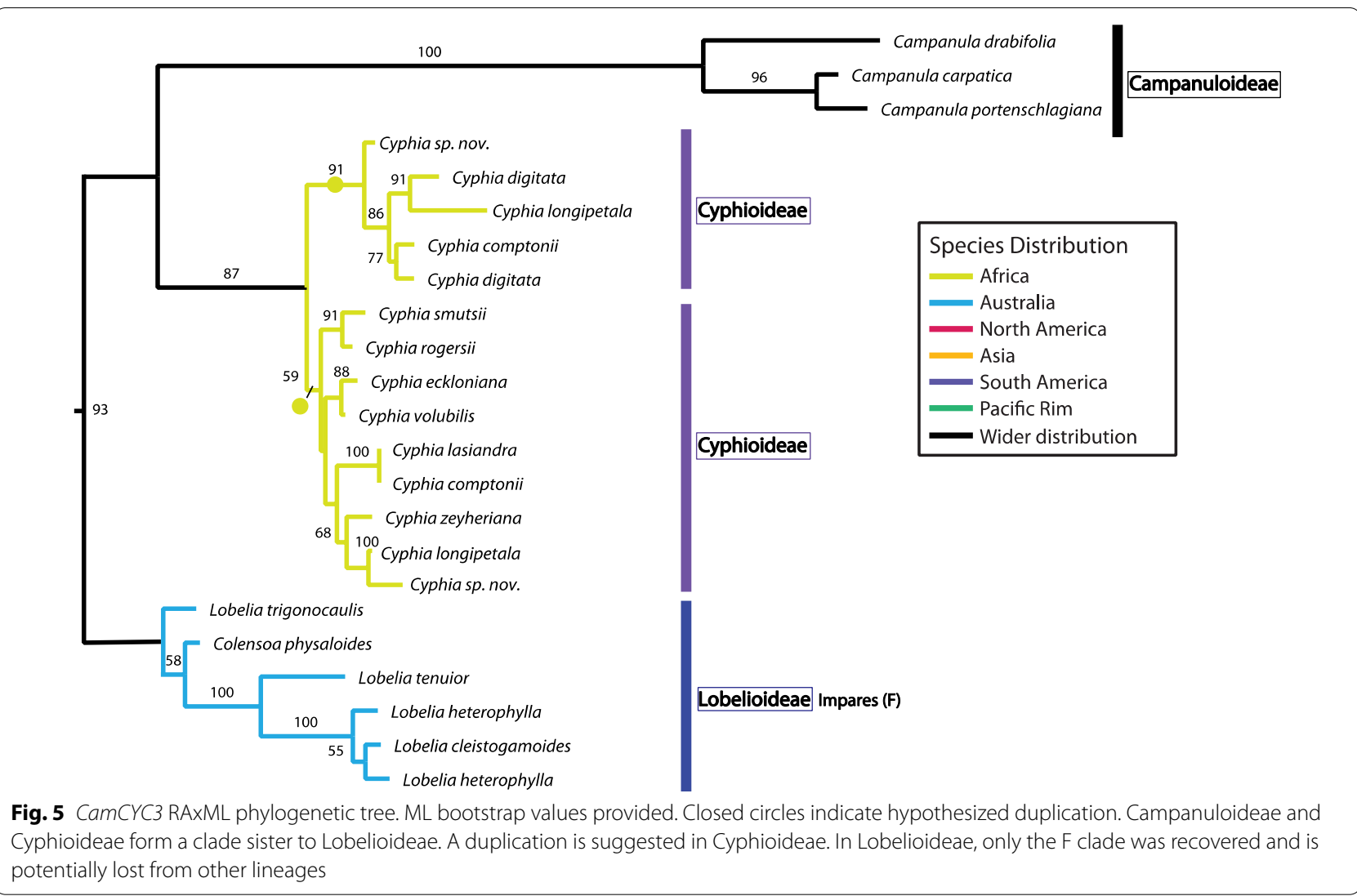

grouped into two clades, and sequences from three species (Cyphia longipetala, C. sp. nov., and C. comptonii) in both clades suggests that CamCYC3 duplicated sometime during the evolution of Cyphia. The very limited recovery of CamCYC3 sequences from the Lobelioideae suggests that this gene has been lost in the subfamily except for the Impares (F) clade.

\section{Expression of CamCYC2 genes in Lobelioideae species}

CamCYC2A and CamCYC2B expression levels were assayed with qRT-PCR across four Lobelioideae species with different floral morphologies, Lobelia erinus (Africa), Lo. siphilitica (North America), Lithotoma axillaris (Australia), and Lo. polyphylla (South America). All four species have typical resupinate Lobeliaceae flowers with a final display having a medial ventral petal lobe (Fig. 6), and all expression patterns are described using dorsal and ventral position of that final display. The overall expression patterns were broadly similar across all four species (Fig. 6A-I, B-I, C-I, D-I), although, the expression levels between the two paralogs varied. In all species, CamCYC2A and Cam CYC2B are strongly expressed in flowers and not leaves, and in most cases the expression levels were not statistically significant across flower bud stages. In the dorsal, lateral, and ventral corolla-lobe dissections across all four species, both $\operatorname{CamCYC2A}$ and Cam$C Y C 2 B$ were highly expressed in the ventral region (adaxial initiation), and only minimally expressed in the dorsal region (abaxial initiation). Cam CYC2A was expressed similarly in lateral and ventral lobes and significantly reduced in dorsal lobes. CamCYC2B was expressed in a gradient, with the highest expression in the ventral lobe, medium expression in lateral lobes, and lowest expression in dorsal lobes. This pattern was consistent among all four species, but which paralog predominated varied among species (Fig. 6A-II, B-II, C-II, D-II).

Lobelia erinus has resupinate flowers with the smallest size ratio of dorsal to lateral and ventral corolla lobes, with the lateral and ventral lobes similar in size, and the dorsal lobes about $15-20 \%$ as large (Figs. 2A, 6). Cam$\mathrm{CYC} 2$ genes are highly expressed in the lateral and ventral lobes (adaxial initiation) and have extremely low expression in the dorsal lobes (abaxial initiation; Fig. 6AII). CamCYC2A is highly expressed in lateral and ventral lobes at similar levels $(p=0.762)$. By contrast, the dorsal lobe expression is significantly lower (dorsal/lateral $p=0.0017$; dorsal/ventral $p=0.0002$ ). CamCYC2B shows a dorsoventral gradient of expression, being most highly 

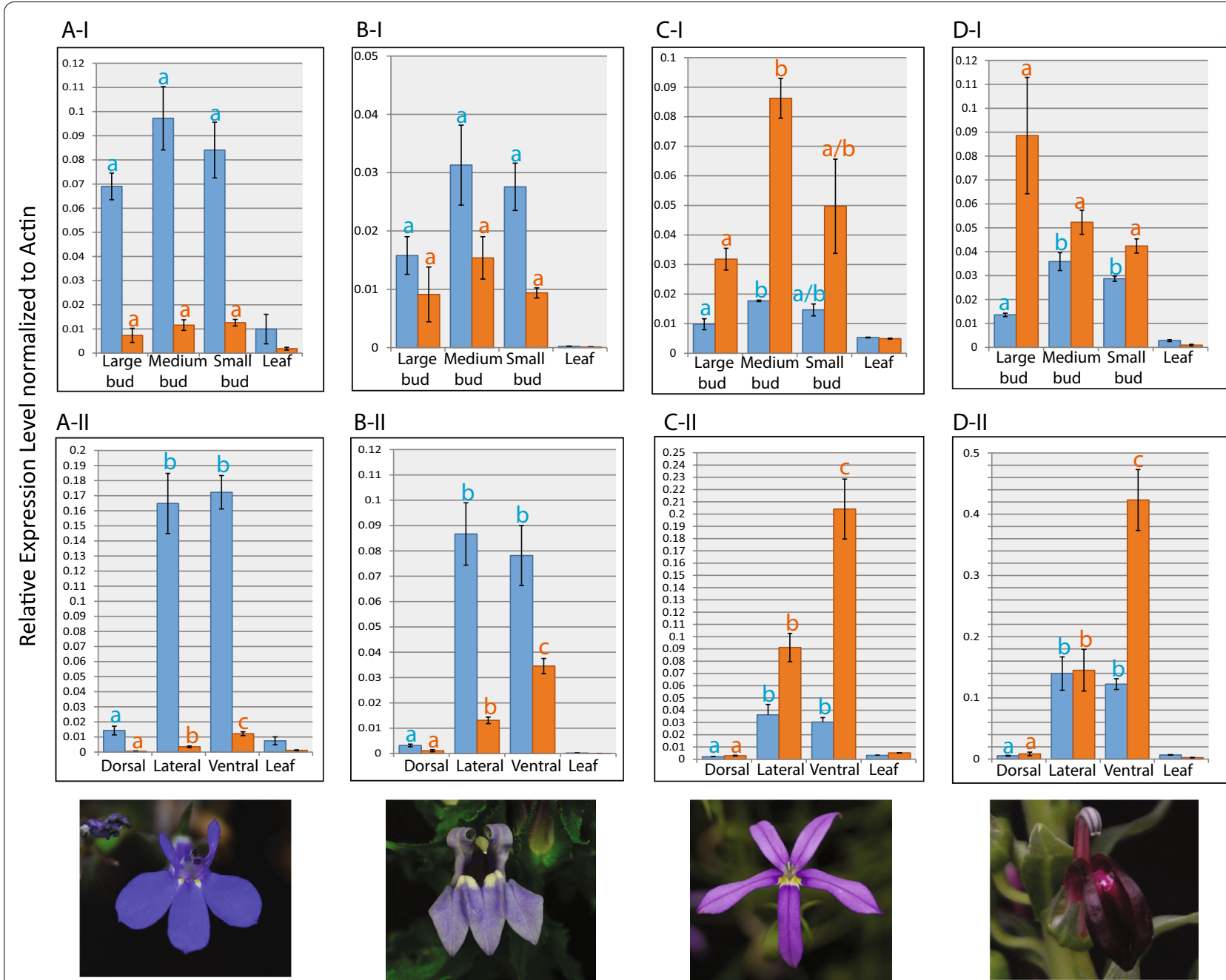

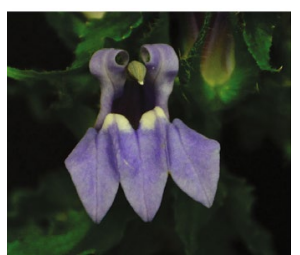

CamCYC2A
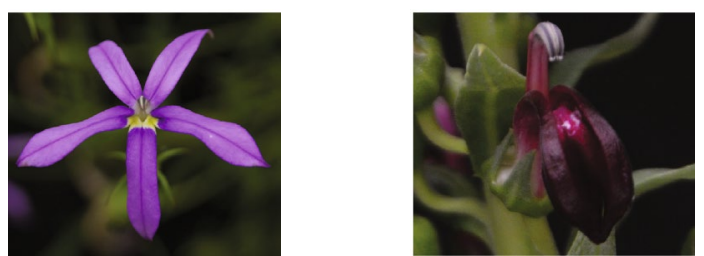

Fig. 6 Relative expression levels of CamCYC2A (blue) and CamCYC2B (orange) genes in Lobelioideae species. A Lobelia erinus, B Lobelia siphilitica, C Lithotoma axillaris, D Lobelia polyphylla. A-I, B-I, C-I, D-I show CamCYC2 genes in different floral bud stages, both CamCYC2 genes are expressed through the whole floral growth stage; A-II, B-II, C-II, D-II show CamCYC2 genes in different corolla lobes from medium buds. CamCYC2A is highly expressed in the ventral and lateral lobes, exhibiting lower expression in dorsal lobes; CamCYC2B is highly expressed in the ventral lobe, exhibiting intermediate expression in lateral lobes and low expression in dorsal lobes. Lines of the Y-axis are labeled with the same scale across all diagrams except (D-II). Y-axis is the relative expression level, normalized to CamACTIN as the reference gene. Levels of expression of a single paralog with statistically significant differences $(p \leq 0.05)$ across different tissues are indicated by separate letters, $a, b$, or $c$. All species resupinate at maturity

expressed in the ventral lobe, moderately expressed in the lateral lobes, and only minimally expressed in the dorsal lobes. The expression of $C a m C Y C 2 B$ was significantly different in the three corolla lobe types (dorsal/ lateral $\mathrm{p}=0.006$; dorsal/ventral $\mathrm{p}=0.0008$; and lateral/ ventral $p=0.0031$ ). Dorsal lobe expression in both Cam$C Y C 2 A$ and $C a m C Y C 2 B$ was similar to leaf expression. Temporally, CamCYC2A and CamCYC2B genes express in very early stages of flower development, and steadily express through bud growth stages, with no significant differences in expression levels in either gene (Fig. 6AI). Comparing the two paralogs, $\operatorname{CamCYC2A}$ is much more highly expressed than $C a m C Y C 2 B$ in floral tissue and flower buds in Lo. erinus. For instance, CamCYC2A expression is roughly 15 times higher than that of Cam$C Y C 2 B$ in the ventral lobe (Fig. 6A-II).

Lobelia siphilitica has resupinate flowers with relatively large dorsal lobes compared with Lo. erinus, and dorsal lobes are about $40 \%$ the size of lateral and ventral lobes (Figs. 1G, 6). The expression patterns of CamCYC2A 
and $C a m C Y C 2 B$ are similar to that of Lo. erinus. In Lo. siphilitica, CamCYC2A is highly expressed in a similar level in lateral and ventral lobes $(p=0.6438)$, and barely expressed in dorsal lobes (dorsal/lateral $\mathrm{p}=0.0025$ and dorsal/ventral $p=0.0032$ (Fig. 6B-II). CamCYC2B is expressed most highly in the ventral lobe, intermediately in the lateral lobes, and extremely minimally in the dorsal lobes (dorsal/lateral $p=0.0009$, dorsal/ventral $p=0.0004$, and lateral/ventral $p=0.0029$ ) (Fig. 6B-II). Temporally, CamCYC2A and CamCYC2B genes express in very early stages of flower development, and steadily express through bud growth stages, with no significant differences in expression levels in either gene (Fig. 6B-I). Similar to in Lo. erinus, CamCYC2A is more highly expressed than $C a m C Y C 2 B$ in floral tissue and flower buds in $L o$. siphilitica, but, with less of a differential between the paralogs. For instance, CamCYC2A expression is only roughly two times greater in the ventral lobe than that of CamCYC2B (Fig. 6B-II).

All five corolla lobes of resupinate Lithotoma axillaris flowers have similar size and shape, but the orientation of the staminal column (with filaments adnate to the fully connate corolla tube, which lacks the dorsal slit to the base typical of Lobelia) makes these flowers bilaterally symmetrical (Figs. 1F, 6). CamCYC2A and CamCYC2B have much higher expression in lateral and ventral lobes and are barely expressed in dorsal lobes, with overall expression patterns similar to Lo. erinus and Lo. siphilitica (Fig. 6C-II). CamCYC2A is significantly less expressed in dorsal lobes than lateral $(p=0.0163)$ and ventral $(p=0.0015)$ lobes, with similar expression between dorsal and lateral lobes $(p=0.5634)$. In Cam$C Y C 2 B$ each lobe type has significantly different expression along a gradient as in the other species, with ventral/ lateral $(p=0.0139)$, ventral/dorsal $(p=0.0012)$, and lateral/dorsal $(p=0.0016)$. Temporally, both paralogs are expressed early and continued to be expressed through development but with a statistically significant decrease in expression in large buds (Fig. 6C-I). In CamCYC2A the difference in expression in large bud versus medium bud is statistically significant $(p=0.0136)$, while other comparisons are not (large bud/small bud $p=0.1508$ and medium bud/small bud $p=0.2016)$. CamCYC2A is consistently expressed through the bud development, with only a slight up-regulation in the medium buds. Cam$C Y C 2 B$ expression peaks in the medium buds, and then decreases in large buds $(p=0.0021)$. A major difference in expression between $\mathrm{Li}$. axillaris and previously discussed Lobelia species is that CamCYC2B is more highly expressed overall, compared to CamCYC2A in floral buds and corolla lobes (more than 7 times greater in ventral lobes). Therefore, the overall expression patterns among lobe types are the same across species, but the gene copy that is the most highly expressed flips.

Lobelia polyphylla has resupinate flowers with dorsal, lateral, and ventral lobes that are similar in size and shape, with the dorsal lobes slightly longer than the lateral and ventral lobes (Figs. 1I; 6). Additionally, all five lobes bend downward and away from the staminal column (toward the finally positioned ventral region in these resupinate flowers). CamCYC2A and CamCYC2B have significantly higher expression in lateral and ventral lobes and are barely expressed in dorsal lobes, with expression patterns similar to Lithotoma axillaris (Fig. 6D-II). CamCYC2A is expressed significantly less in dorsal lobes than lateral $(p=0.0079)$ and ventral $(p=0.0002)$ lobes, with similar expression between dorsal and lateral lobes $(p=0.5783)$. In $C a m C Y C 2 B$ there is a dorsoventral gradient of expression, highest in ventral corolla lobes, with each lobe type having significantly different expression between dorsal/ lateral $(p=0.0161)$, dorsal/ventral $(p=0.0011)$, and lateral/ventral $(p=0.0099)$ lobes. Temporally, both paralogs are expressed early and continue to be expressed through development, but with a statistically significant decrease in expression in large buds in only $\mathrm{CamCYC} 2 \mathrm{~A}$ (Fig. 6D-I). In CamCYC2A, expression in large buds is significantly less than that of small buds $(p=0.0004)$ or medium buds $(p=0.0042)$. In Lo. polyphylla CamCYC2B

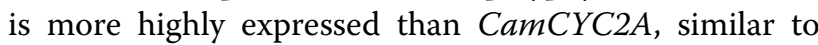
the pattern observed in $L i$. axillaris, with $C a m C Y C 2 B$ roughly 3.5 times more highly expressed than Cam$C Y C 2 A$ in the ventral lobe.

\section{Discussion}

The three subfamilies of Campanulaceae sampled in this study have distinctly different floral symmetry modifications with radially symmetrical flowers in Campanuloideae, non-resupinate bilaterally symmetric flowers in Cyphioideae, and bilaterally symmetric flowers that are predominately $180^{\circ}$ resupinate in Lobelioideae $[1,2,7]$. In these three groups, we uncovered broad gene duplications and losses that correlate with these morphological shifts. We detected all three core eudicot $C Y C$-like genes from the CYC1, CYC2, and CYC3 clades [41]. CamCYC1 was thoroughly sampled from all three subfamilies, while CamCYC2 was likely lost in Cyphioideae and CamCYC3 was likely lost from all except the Impares (F) subclade of Lobelioideae (which along with the Genistoid (E) subclade is sister to the rest of the subfamily; Knox 2014). Additionally, we found evidence for subfamily duplications-CamCYC1 duplicated in Campanuloideae, CamCYC2 duplicated in Lobelioideae, and CamCYC3 duplicated in Cyphioideae (Fig. 7). 


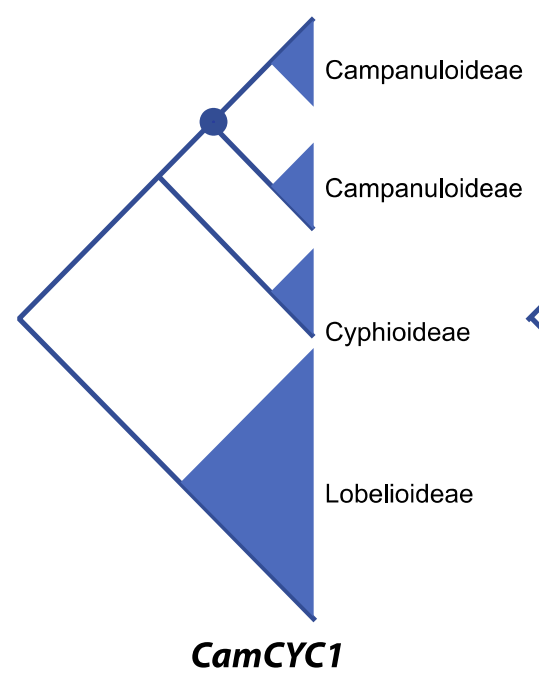

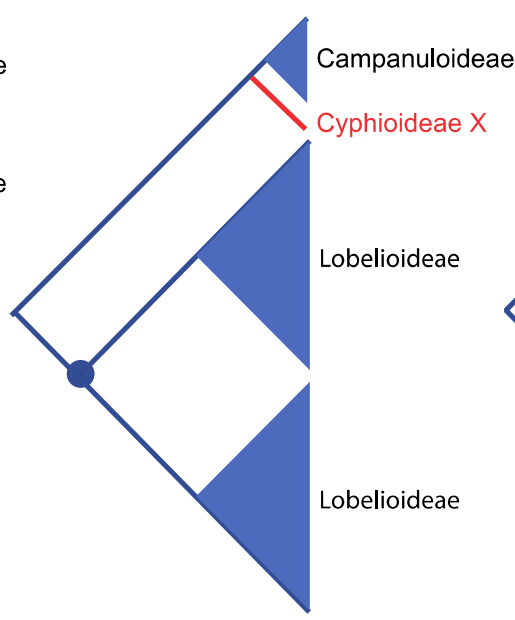

CamCYC2

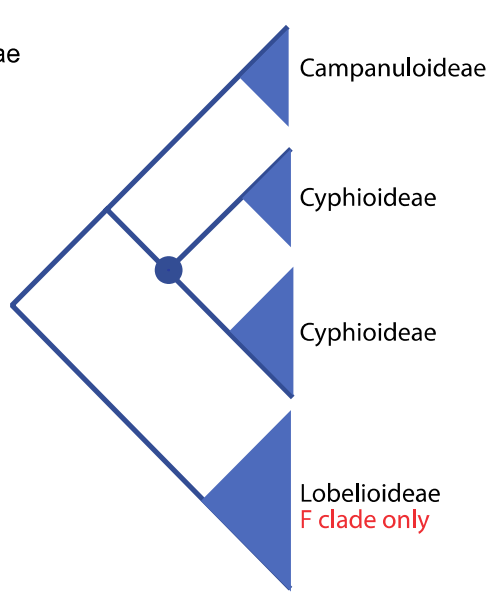

CamCYC3

Fig. 7 Summary CYC-like duplication events across Campanulaceae. CamCYC1 duplicated in Campanuloideae and might have narrower duplications in the F and $\mathrm{U}$ clades in Lobelioideae. CamCYC2 showed a clear duplication event specific to Lobelioideae and an apparent loss in Cyphioideae. CamCYC3 duplicated in Cyphioideae and is apparently lost in all but one clade of Lobelioideae. CamCYC3 might play a key role in bilateral symmetry instead of CYC2-like genes in Cyphioideae. Blue dots indicate hypothesized location of broadly duplicated clades

\section{CamCYC1 duplicated in the radially symmetric Campanuloideae}

CamCYC2-the Campanulaceae member of $\mathrm{CYC2}$, which is a clade that has shown functional conservation in patterning floral bilaterally symmetry [28, 30, $41,50,51]$-was present across the radially symmetrical Campanuloideae, from four species that span the major clades of the group (Fig. 3). There was no evidence for duplications in $\mathrm{CamCYC2}$, which is consistent with other radially symmetrical groups [39, 41]. Additionally, Campanuloideae CamCYC2 copies had high sequence diversity, being on very long branches, and were therefore difficult to align with Lobelioideae species (Fig. 4). In other lineages with both radially symmetrical and bilaterally symmetrical flowers, such as Fabales, Malpighiales, and Dipsacales, species with radially symmetrical flowers have CYC2-like genes expressed uniformly across the whole corolla or have lost floral expression entirely [36, 38, 40, 52-58].

Cam CYC3 was also found in Campanuloideae, but only in the $\mathrm{C} 2$ clade [3] and also on a long branch compared to Cyphioideae and Lobelioideae sequences (Fig. 5). CYC3 has been shown to be involved in axillary bud outgrowth [44] and in floral symmetry [40], but with variable function in different plant groups.

The Campanuloideae show the most diversification in CamCYC1 genes, with a duplication possibly shared across the Campanuloideae clade (Figs. 3, 7). With only minor differences, these duplicate gene trees agree with the estimated Campanuloideae species phylogeny [2, 3]. Studies in plant groups across core eudicots suggest that
CYC1 genes are functionally conserved, regulating the number and position of axillary bud development [4244], as well as inflorescence architecture and development [37]. Loss-of-function mutants in Arabidopsis and Populus lead to a marked increase in bud outgrowth and plant branching [42-44]. It is possible that the duplication of CamCYC1 set the stage for the variation in plant and inflorescence architecture in Campanuloideae. Flowers vary from solitary to complex inflorescences such as capitulate heads [1]. Broad duplications in CYC1 are less common than in the other $C Y C$ clades, although they are consistently duplicated in lineages known for capitulate heads such as in the Asteraceae [31, 45], Dipsacaceae [59], and Actinodium [35].

\section{Cyphioideae have lost CamCYC2 and duplicated CamCYC3}

Cyphioideae typically have non-resupinate bilaterally symmetrical flowers with a $3+2$ form, with one dorsal lobe, two lateral lobes, and two ventral lobes. In all other core eudicot bilateral symmetrical lineages studied to date, $C Y C 2$ is differentially expressed across the dorsoventral axis and functions to pattern that bilateral symmetry [39]. Occasionally, CYC2 genes appear to lose floral expression or be lost from the genome of certain species, however, these are always marked by shifts to radial symmetry $[53,54,56,57]$. Additionally, in almost all cases, $C Y C 2$ genes are duplicated in bilaterally symmetrical lineages $[39,41]$. Here we report the first case of an apparent loss of $\mathrm{CYC} 2$ in a bilaterally symmetrical core eudicot group, Cyphioideae (Fig. 7). Sampling nine species with multiple primer sets, no $\mathrm{CamCYC2}$ 
sequences were found, despite easily recovering them from Campanuloideae and Lobelioideae.

Along with a likely loss of $\mathrm{CYC} 2$ in Cyphioideae, $\mathrm{Cam}$ CYC3 appears to be duplicated in this lineage (Figs. 5, 7). This is in stark contrast to Lobelioideae, which appear to have lost CamCYC3 in all but the Impares (F) clade, with no evidence of gene duplication. CYC3 is the most understudied paralog across core eudicots and also appears to be the most variable in function. $C Y C 3$ genes are duplicated in some groups such as Dipsacales and Asteraceae $[45,59,60]$, but have been likely lost in others such as Leguminosae and Gesneriaceae $[61,62]$. In Arabidopsis (Brassicaceae) and Populus (Salicaceae), CYC1 (Branched1) and CYC3 (Branched2) orthologs have redundant function in regulating bud outgrowth $[44,63]$ with an increase in branching in loss-of-function mutants. Interestingly, branched 1 had the stronger phenotype in Arabidopsis [44] and branched2 had the stronger phenotype in Populus [63]. Although CYC3 gene function in floral symmetry has not previously been shown, studies in Dipsacales and Asteraceae reported expression patterns that are suggestive of this role, with dorsoventral expression of KmCYC3B in Knautia macedonica [40] and $\mathrm{HaCYC} 3 a$ expression specific to ray florets in Helianthus annuus [37]. This evidence suggests that $C Y C 3$ function is highly labile. Additionally, function specific to plant branching appears to be found in rosids while floral expression has been seen in campanulid asterids. $C Y C 3$ could play a role in floral symmetry in campanulids such as Cyphia, and is possibly filling the role of the lost $C Y C 2$.

Even though Cyphioideae are bilaterally symmetrical, their genetic signature compared to other core eudicot species would actually suggest they are radially symmetrical, with an apparent loss of functional CYC2-like genes. In the latest phylogenetic analyses [2] Cyphioideae are sister to radially symmetrical Campanuloideae, which retain $C Y C 2$-like genes, however, they are highly diverged. Additionally, Cyphioideae are not resupinate as are most species of Lobelioideae. However, unlike the lobe arrangement of most bilaterally symmetrical core eudicots, Cyphia flowers (Fig. 1J, K) have 3 dorsal corolla lobes and 2 ventral lobes. Standard orientation of core eudicot bilaterally symmetrical flowers have a single ventral corolla lobe, pointed downward, with two lateral and two dorsal lobes each acting as pairs that can shift along the dorsoventral axis in tandem [17]. Campanuloideae and Lobelioideae have medial ventral petal lobes [64], but the later only after resupination via torsion of the pedicel $[65,66]$. The lobe arrangement in Cyphioideae, with a $3+2$ corolla lobe arrangement, necessitates a shift in that axis at some point early in development, possibly through an independent resupination event or differentiation in the location of primordial initiation. The latter is suggested by Leins and Erbar [67] with initiation of petal lobe primordia in a $3+2$ arrangement, however, with asymmetric early development across the dorsoventral axis. Therefore, these data support the hypothesis that the ancestral Campanulaceae was radially symmetri$\mathrm{cal}$ and that the genetic programming of bilateral symmetry likely evolved independently in Cyphioideae and Lobelioideae.

\section{In Lobelioideae, CamCYC1 duplicated within two subclades while CamCYC3 appears to be lost in all but the Impares clade}

In Lobelioideae, CamCYC1 is broadly congruent with the hypothesized species phylogeny with no obvious subfamily-wide duplications (Figs. 3, 7) [7-10, 46, 47]. There are multiple sequences in a few species; however, these are likely alleles or more recent isolated duplications. CamCYC1 has not been implicated in bilateral symmetry in any groups, instead being involved in plant and inflorescence branching in several lineages [44, 63, 68]. Cam$C Y C 1$, in keeping with the general paucity of CYC1 gene duplications found in other groups, lacks the broad duplication pattern commonly seen in $C Y C 2$ and $C Y C 3$ genes correlating with a shift to bilateral symmetry $[45,60,62]$. However, there are duplications found in the Impares $(\mathrm{F})$ clade as well as the giant lobelioids (U), likely due to independent ancient genome duplications [48, 49,69].

The Impares clade, appearing to have duplicated CamCYC1 early in its diversification (Fig. 3), is notable for having a diversity of chromosome numbers, varying among 8, 9, 10, and 11 [69], while most of Lobeliaceae have multiples of 7 chromosomes. This suggests that a genome duplication occurred early in the diversification of the Impares clade, followed by subsequent frequent chromosome losses. The duplication in CYC1 likely correlates with that genome duplication; however, we have no hypothesis for why these genes were maintained in this lineage. The Impares clade also appears to be the only group to have retained $\mathrm{CamCYC} 3$ genes (Figs. 5, 7). This means that this lineage maintains both an extra $C Y C 1$ and an extra $C Y C 3$ gene compared to most other Lobelioideae clades. The Impares corolla shape does differ from other groups in having large, broad ventral and lateral corolla lobes and greatly reduced, nearly scale-like dorsal lobes [70]. However, there are no data that tie this morphology with extra $C Y C 1$ and $C Y C 3$ gene copies to date.

The giant lobelias (U clade) primarily grow in tropical montane habitats around the globe and have synapomorphies of a tree-like habit, often with lignification, and are tetraploid with a chromosome number of $n=14$ [7, 10, 71]. In the U clade, there are 3 subclades of CamCYC1, 
with the U1 clade grouping with other Neotropical, Australia, and South American Lobelioideae species sister to a clade including U2A and U2B. The current topology suggests separate duplications in Pacific Basin species (Fig. 3, green) and non-Pacific Basin species (Fig. 3, yellow); however, there was no bootstrap support for the relationships of these clades, so a single duplication could be shared across all the giant lobelias. These groups were difficult to tease apart because sequence divergence is minimal and they were amplified and cloned together, which resulted in some mixing of sequences among copies. Nevertheless, $C Y C 1$ duplicates are maintained in the giant lobelias, and better sampling could shed light on the precise ancestor(s) of this clade. For instance, in the U1 clade, Lobelia doniana is sister to the rest, supporting the East Asian origin hypothesis of giant lobelias [46], although they are nested within a grade of North American species.

\section{Duplication of CamCYC2 in Campanulaceae is highly associated with bilateral symmetry in Lobelioideae} CamCYC2 genes are the orthologs of CYCLOIDEA, a gene which has been shown repeatedly to exhibit dorsally restricted expression in bilaterally symmetrical groups (see Hileman [39]). Additionally, the evolution of bilateral symmetry has been correlated with duplications in $C Y C 2$ genes $[39,60]$. These genes are of interest in bilaterally symmetrical species of Campanulaceae, where we expect gene expression to be restricted to one side of the flower and that duplications will likely be frequent. CamCYC2 in Lobelioideae was well-sampled and, as expected, had a clear duplication across the entire clade (Figs. 4, 7). The CamCYC2 duplication very likely occurred in the Lobelioideae ancestral lineage after it diverged from Campanulaceae sensu stricto. Both Lobelioideae CamCYC2 gene clades share a similar pattern and are broadly congruent both with previous research $[8,10,46,47]$ and with the Lobelioideae CamCYC1 gene clade. As in CamCYC1, we also detected duplications in the $\mathrm{U}$ subclade in both CamCYC2 paralogs, likely due to tetraploidy. Flowers of Lobelioideae are resupinate, twisting their pedicel (Fig. 2A, C). However, since mature flowers, after turning, end up having a flower that looks right side up (i.e., a standard core eudicot $2+3$ lobe arrangement); this suggests there is a developmentally earlier change in orientation to create an initial 3 up, 2 down lobe arrangement. Taxa such as species in Monopsis (G) do not twist their pedicel and end up with mature $3+2$ flowers, reverting to the hypothesized ancestral Lobelioideae flower orientation. That said, Monopsis species did not lose their CamCYC2 copies like Cyphioideae, which similarly does not undergo resupination. There are currently no known genes involved in twisting of plant tissues, for instance, to present the flower upside down, allowing us to potentially uncover novel gene functions of CYC-like genes with further studies of these groups.

Within both of the CamCYC2A and CamCYC2B clades, the U subclade (giant lobelias) occur in two duplicate locations in the phylogeny, likely due to their tetraploid ancestry [48, 49]. This means that there are four separate clades of $C Y C 2$ in giant lobelias. One of the $\mathrm{U}$ clades in each of CamCYC2A and CamCYC2B have no clear sister group; however, the other clade in each is most-closely related to Lobelia urens. This relationship to Lo. urens is not well-supported in either clade, and Lo. urens is clearly part of a Mediterranean clade likely derived by amphitropical dispersal from what is now the Western Cape of South Africa [46]. Two species in the Tupa group of South America have evolved woody growth independently from the giant lobelias $[5,10,46]$. The hexaploid Tupa group [19] appears to have independently duplicated in $\operatorname{CamCYC2B}$, similar to the giant lobelia (U) group.

\section{Gene expression of CamCYC2 in Lobelioideae species is conserved following resupination and paralog dominance is correlated with dorsal petal size}

In Lobelioideae species, we isolated two copies of CamCYC2 genes and utilized qRT-PCR to examine their temporal and spatial expression patterns. As previous researchers have shown, CYC2-like genes are dorsally restricted, limited to the adaxial region of flower tissues. In most examined bilaterally symmetrical species, $C Y C 2$ like paralogs are diverged in their expression, with one copy being more restricted dorsally than the other [36, 39]. Lobelioideae have resupinate flowers and we hypothesized that CamCYC2 expression would, like other bilaterally symmetrical flowers, be adaxial, corresponding to finally positioned ventral in these resupinate flowers. Using four Lobelioideae species, Lobelia erinus, Lo. siphilitica, Lo. polyphylla, and Lithotoma axillaris, we found that (1) the paralogs varied in how restricted they were on the dorsoventral axis, (2) that resupinate flowers led to the highest expression in finally positioned ventral regions, and (3) the overall patterns of expression among lobes was similar across species; however, which paralog exhibited greater expression varied (Figs. 6, 8).

The temporal expression patterns of $\mathrm{CamCYC2}$ genes were relatively uniform through development, which is similar to that observed in other groups [21]. The spatial expression patterns of $\mathrm{CamCYC} 2 \mathrm{~A}$ and $\mathrm{CamCYC2B}$ are relatively concordant among the four species (Figs. 6AII, B-II, C-II, D-II, 8). CamCYC2A is expressed similarly in lateral and ventral lobes, or the whole ventral region of the flower (the adaxial region) and has very low 
expression in the dorsal lobes (abaxial initiation). Cam$C Y C 2 B$ is always highly expressed in the ventral lobe (adaxial initiation), has an intermediate expression level in lateral lobes, and is barely expressed in dorsal lobes (abaxial initiation). Both CamCYC2A and CamCYC2B have little to no expression in the dorsal lobes, similar to leaf expression. A similar phenomenon is seen in Malpighiaceae, with a shift in the axis of the early flower primordia resulting in a rearrangement of floral petals in the New World Malpighiaceae species, which have 1 dorsal petal, 2 lateral petals, and 2 ventral petals. The expression CYC2-like genes in Malpighiaceae, however, remains in the dorsal regions of the corolla [56-58].

Previous work in Dipsacales has shown that even subtle differences in the dorsoventral gradient of $C Y C 2$ expression is correlated with significantly different growth patterns of the lobes [40]. In Lobelia erinus, flowers with small dorsal lobes, $\operatorname{CamCYC} 2 A$ is significantly more expressed than CamCYC2B (Fig. 6A-II). In Lo. siphilitica, flowers with relatively larger dorsal lobes than Lo. erinus, the pattern is the same, but the distinction between the level of expression is not as great, especially in the ventral lobe where the $\operatorname{CamCYC2B}$ gene expression level is almost $50 \%$ of the CamCYC2A gene expression level (Fig. 6B-II). In Lithotoma axillaris and Lo. polyphylla, there is no distinct difference in shape or size between dorsal, lateral, and ventral lobes. In an opposite pattern, the $C a m C Y C 2 B$ gene is more highly expressed than the CamCYC2A gene (Fig. 6C-II, and D-II). This is effectively an increase in expression of the gene with the broader zone of expression, which has been shown to be correlated with a more radialized flower [36]. In flower primordia, $C Y C$ genes repress cell growth and control organ number, and in later stages, $A$. majus $C Y C 2$ paralogs can also upregulate cell division $[26,28]$. In this case, Lobelioideae species have relatively larger lateral and ventral lobes (the genetically adaxial region), likely due to the high CamCYC2 gene expression. However, it does not easily explain how Li. axillaris and Lo. polyphylla flowers have lobes with almost the same size and shape. Nonetheless, this change in the expression ratio among paralogs sets up an intriguing system to study not just CYC function and evolution, but also how morphology can be substantially altered by shifts in expression dominance among gene paralogs.

\section{Conclusions}

Campanulaceae are a large core eudicot clade that exhibits a variety of floral symmetries, including varying types of resupination and pollination syndromes. The family occurs nearly world-wide and has become a model
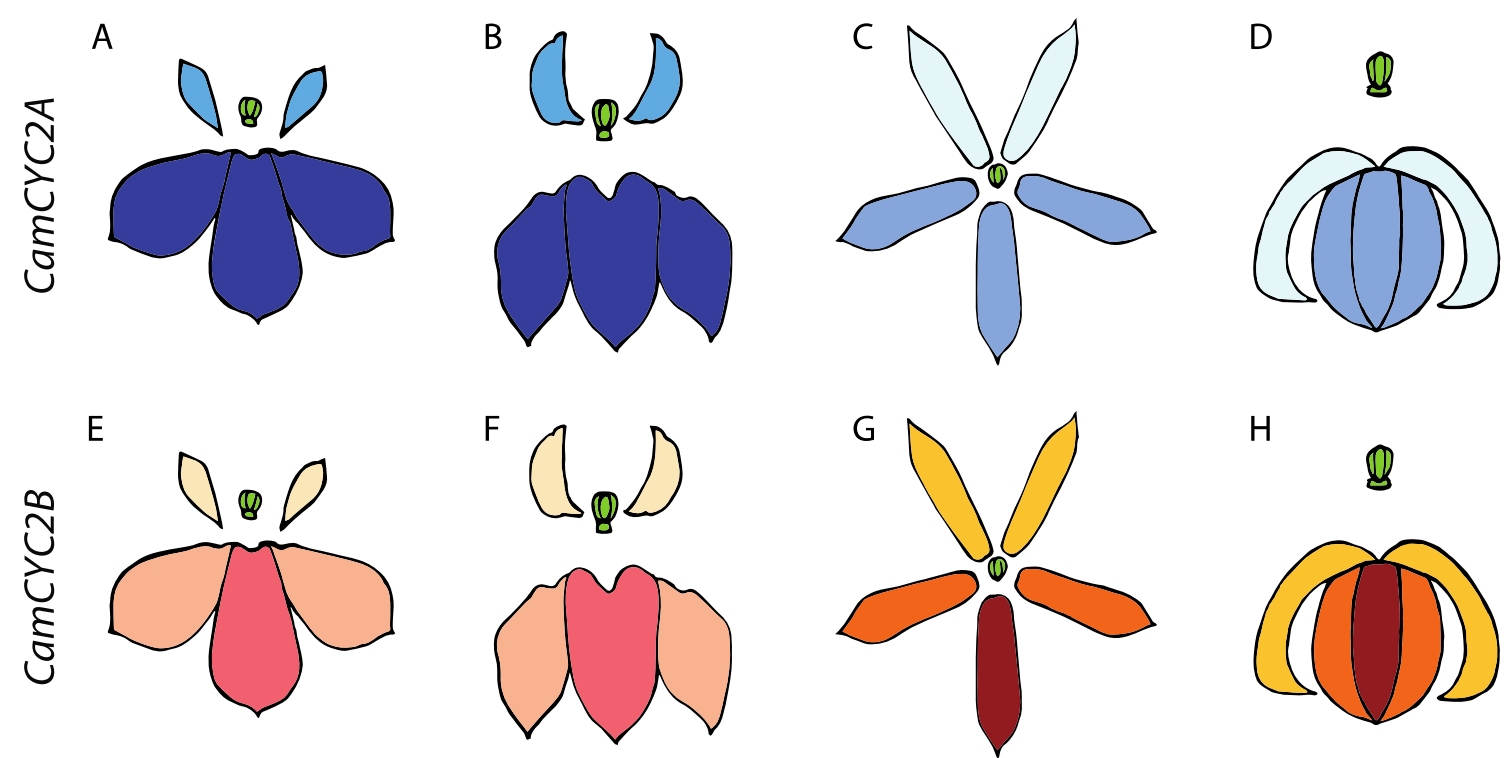

Fig. 8 CamCYC2A and CamCYC2B expression pattern in Lobelioideae species. A-D CamCYC2A expression pattern, E-F CamCYC2B expression pattern. A, E Lobelia erinus, B, F Lobelia siphilitica, C, G Lithotoma axillaris, D, H Lobelia polyphylla. Low saturation of color represents minor expression, high saturation of color represents high expression in flower buds. CamCYC2A is more highly expressed in species with relatively small dorsal corolla lobes, (A, B) while CamCYC2B is the more highly expressed in species with relatively large dorsal corolla lobes $(\mathbf{G}, \mathbf{H})$. CamCYC2A is weakly expressed in the dorsal corolla lobes (the true ventral domain) and is highly expressed in the ventral domain (the true dorsal domain). CamCYC2B has weak expression in the dorsal corolla lobes (the true ventral corolla lobes), medium expression in lateral corolla lobes, and high expression in the ventral corolla lobe (the true dorsal corolla lobe) 
for studying adaptive radiations in many locations. We sequenced all three core eudicot paralogs of CamCYC genes, CamCYC1, CamCYC2, and CamCYC3 (Fig. 7). The CamCYC1 genes duplicated in radially symmetrical Campanuloideae, but not in other bilaterally symmetrical flower subfamilies. As expected, CamCYC2 genes duplicated in the Lobelioideae clade with bilaterally symmetrical flowers. However, we show for the first time a loss of CYC2-like genes in a bilaterally symmetrical group, with no sequences found in Cyphioideae. Instead of Cam$C Y C 2$, we found a potential duplication of $\mathrm{CamCYC3}$ in this group. It is possible that, in Cyphioideae, Cam$C Y C 3$ genes may have taken on the role of $C Y C 2$-like genes. Future studies examining floral RNA expression in Cyphia should be highly informative. Nonetheless, the genetic programming of floral symmetry appears to be independently derived in Cyphioideae and Lobelioideae, supporting the hypothesis that ancestral Campanulaceae were radially symmetrical.

In Lobelioideae, expression patterns of CamCYC2 genes were similar to previous studies across core eudicots species, with $\operatorname{CamCYC2A}$ and $C a m C Y C 2 B$ both highly expressed in the adaxial side of flower related to meristem orientation (Fig. 8), despite resupination resulting in a ventral presentation in the flower, suggesting conservation of dorsal identity in these upside-down flowers. In addition, the $\operatorname{CamCYC} 2 A$ and $C a m C Y C 2 B$ show distinctly different expression patterns in species with a different dorsal lobe size ratio. $\operatorname{Cam} C Y C 2 A$ is the dominant CamCYC2 gene in species with smaller dorsal lobes, like Lobelia erinus, and Lo. siphilitica. CamCYC2B is the dominant CamCYC2 gene in species with bigger dorsal lobes, in which the dorsal lobes are almost the same size as the lateral and ventral lobes, like Lithotoma axillaris and Lo. polyphylla. We illustrate here for the first time that $C Y C$ expression is conserved along the dorsoventral axis of the flower even as it turns upside-down, suggesting that at least later $C Y C$ expression is not regulated by extrinsic factors such as gravity. Additionally, the shift in expression dominance among paralogs provides intriguing data that differences in ratios of expression in $C Y C$ could lead to shifts in morphological growth ratios in the flower.

\section{Materials and methods}

\section{Sampling and plant materials}

We examined a total of 132 DNA samples from 128 species, including nine Cyphioideae species, nine Campanuloideae species, and 110 Lobelioideae species. Table 1 provides DNA source information for previously prepared samples. An additional eight Campanuloideae and eight Lobelioideae species were from live plants growing in the greenhouse at St. John's University.
Table 2 Primers for different CYC paralogs in Campanulaceae

\begin{tabular}{lll}
\hline Locus & Primer & Primer sequences $\left(\mathbf{5}^{\prime}\right.$-3') \\
\hline CYCLOIDEA1 & Astl CYC1Fa & CGRAGRATGAGRYTRTCNCTTGATG \\
& Astl CYC1Ra & GCCCTTKCYCTTGCYCTTTCCCTTG \\
CYCLOIDEA2 & CYC73b & GCNCGNARRTTYTTYGATCTDCAAG \\
& CYCRa & CTTGCTCTTTCYCTYGCYTTYGCCC \\
CYCLOIDEA3 & CYC73b & GCNCGNARRTTYTTYGATCTDCAAG \\
& CYCRa & CTTGCTCTTTCYCTYGCYTTYGCCC \\
& AstI CYC3Fa & GGGAAGAMAGAYMGGCAYAGC \\
& Astl CYC1Ra & GCCCTTKCYCTTGCYCTTTCCCTTG \\
\hline
\end{tabular}

Campanula persicifolia was wild collected in Fresh Meadow, New York. Campanula carpatica was bought from a local nursery garden. Campanula glomerata, Campanula portenschlagiana, Campanula cochleariifolia, Jasione montana, Platycodon grandiflorus, Phyteuma scheuchzeri, Lobelia anceps, Lobelia bridgesii, Lobelia cardinalis, Lobelia erinus, Lobelia siphilitica, Lobelia polyphylla, Lobelia tupa, and Lithotoma axillaris seeds were ordered from online plant nurseries (Botanical Interests ${ }^{\circledR}$, Hazzard's Seeds, and Plant World Seeds). All DNA was extracted using a DNeasy Plant Mini Kit (QIAGEN) according to the manufacturer's instructions and stored in $-20{ }^{\circ} \mathrm{C}$.

\section{Amplification}

All PCR reactions were performed using Taq DNA Polymerase $\left(G_{0} T_{a q}{ }^{\circledR}\right.$ Flexi DNA polymerase, Promega). All DNAs were amplified in $25 \mu \mathrm{L}$ PCR reactions containing: $1 \mu \mathrm{L}$ DNA, $5 \mu \mathrm{L} 5 \times$ buffer, $2.5 \mu \mathrm{L} 25 \mathrm{mM}$ $\mathrm{MgCl}_{2}, 0.5 \mu \mathrm{L} 10 \mathrm{mM}$ dNTPs, $1 \mu \mathrm{L}$ of $10 \mathrm{mM}$ primers, $1 \mu \mathrm{L} \mathrm{Taq}$ polymerase, and distilled water was added to bring up to total volume. Amplifications utilized the following cycling program: (1) initial denaturation was carried out at $94{ }^{\circ} \mathrm{C}$ for $2 \mathrm{~min}$; (2) 39 cycles of: $94^{\circ} \mathrm{C}$ for $45 \mathrm{~s}, 51{ }^{\circ} \mathrm{C}$ (varied for by different pairs of primers) for $1 \mathrm{~min}$, and $72{ }^{\circ} \mathrm{C}$ for $1 \mathrm{~min} 30 \mathrm{~s}$; (3) a final elongation step at $72{ }^{\circ} \mathrm{C}$ for $20 \mathrm{~min}$. To amplify $\mathrm{C} Y \mathrm{C}$-like genes in Campanulaceae, previously designed degenerate primers were used from Howarth and Donoghue [41]. Primers for CamCYC1 were designed based on CYC-like sequences from other lineages in asterids available from NCBI. All primer sequences are provided in Table 2.

Cloning was performed using the StrataClone PCR Cloning Kit (Agilent, Santa Clara, CA), following the manufacturer's instructions. We picked four to eight colonies per plate and amplified them using primer sites in the construct (M13F and M13R). DNA cleaning utilized the P.E.G. method [72]. Sanger sequencing 
Table 3 The $q$ RT-PCR primers for each species examining CamCYC2A and CamCYC2B gene expression patterns

\begin{tabular}{|c|c|c|}
\hline & & Efficiency (\%) \\
\hline & Lobelia erinus & \\
\hline \multirow[t]{2}{*}{ CamCYC2A } & CYC2 37F 5'-GCTAGTAAAACCCTTGATTGGCT-3' & $\underline{82.7}$ \\
\hline & CYC2A 314R 5'-GCCCTGGACTCTTTTTGCAAAGT-3' & \\
\hline \multirow[t]{2}{*}{ CamCYC2B } & CYC2 37F 5'-GCTAGTAAAACCCTTGATTGGCT-3' & 81.8 \\
\hline & CYC2B 291R 5'-GCGATGAGATGCAGGTTTATAACTG-3' & \\
\hline \multirow[t]{3}{*}{ CamActin } & Le-act1046F 5'-ATCCACGARACSACCTACAACT-3' & 86.0 \\
\hline & Le-act1216R 5'- MACCACCTTAATCTTCATGCTGCT-3' & \\
\hline & Lobelia siphilitica & \\
\hline \multirow[t]{2}{*}{ CamCYC2A } & Is CYC2A-37F 5'-TTCGACAAAGCTAGTAAAACTCTTGATTGG-3' & 81.6 \\
\hline & Ls CYC2A 264R 5'-TTTCTCTTTGGCTCTCGTTGTAGC-3' & \\
\hline \multirow[t]{2}{*}{ CamCYC2B } & Is CYC2B-47F 5'-CTAGTAAAACCCTTGATTGGCTTTTCAC-3' & 87.0 \\
\hline & Ls CYC2B 298R 5'-CTAGGCGATGAGATGCAGGTTTATAAC-3' & \\
\hline \multirow[t]{3}{*}{ CamActin } & Le-act477F 5'-AGATYTGGCATCAYACTTTCTACA-3' & 89.0 \\
\hline & Le-act729R 5'- CCTTCGTARATTGGAACCGTGTG-3' & \\
\hline & Lithotoma axillaris & \\
\hline \multirow[t]{2}{*}{ CamCYC2A } & Ls CYC2A F41 5'-ACAAAGCTAGTAAAACTCTTGATTGGCT-3' & 89.3 \\
\hline & ISCYC2A 260R 5'-TTCTCTTTGGCGCTCGATGTAGCTG-3' & \\
\hline \multirow[t]{2}{*}{ CamCYC2B } & ISCYC2B 38F 5'-TTGACAAAGCTAGTAAAACCCTTGATTGG-3' & 92.8 \\
\hline & ISCYC2B 203R 5'-GCTCCTTCATTTTGTTCAGCTGC-3' & \\
\hline \multirow[t]{3}{*}{ CamActin } & Le-act1046F 5'-ATCCACGARACSACCTACAACT-3' & 86.0 \\
\hline & Le-act1216R 5'-MACCACCTTAATCTTCATGCTGCT-3' & \\
\hline & Lobelia polyphylla & \\
\hline \multirow[t]{2}{*}{ CamCYC2A } & LP CYC2AF1a 5'-TCGACAAAGCTAGTAAAACTCTTGATTGG-3' & 89.6 \\
\hline & LP CYC2A R4 5'-TTTGCAAGATAAAGTGCAGGTTTATACG-3' & \\
\hline \multirow[t]{2}{*}{ CamCYC2B } & Ls CYC2B F43 5'-AAAGCTAGTAAAACCCTTGATTGGCT-3' & 85.7 \\
\hline & LP CYC2B R1 5'-TTTGTGCTCTCATCGTTTTCGCTTCAC-3' & \\
\hline \multirow[t]{2}{*}{ CamActin } & Le-act477F 5'-AGATYTGGCATCAYACTTTCTACA-3' & 89.0 \\
\hline & Le-act729R 5'-CCTTCGTARATTGGAACCGTGTG-3' & \\
\hline
\end{tabular}

The annealing temperature for all primers is $60^{\circ} \mathrm{C}$

was performed at the Yale University DNA Analysis Facility, New Haven, CT, using a 3730xl DNA Analyzer (Applied Biosystems, Thermo Fisher Scientific, Inc.).

\section{Alignment and phylogenetic analyses}

All individual colony sequences were edited in Geneious ${ }^{\circledR}$ Pro v.7.1.2 (http://www.geneious.com), including removing the plasmid and primer sequences. Consensus sequences were generated from similar clones from the same DNA sample. To determine orthology, we initially used BLAST in NCBI. CYC-like genes were determined by the presence of the TCP and R domains. The specieslevel consensus sequences were aligned in Geneious ${ }^{\circledR}$ using the MUSCLE Alignment tool (default parameters) and then manually adjusted according the amino acid sequences or nucleotide sequences in Mesquite [73] or Geneious $^{\circledR}$ Pro v.7.1.2. The phylogenetic gene trees were generated with CIPRES science gateway (https:// www.phylo.org) using Maximum Likelihood by the
RAxML-HPC BlackBox (default parameters, except with added option to let $\mathrm{RA} \times \mathrm{ML}$ halt bootstrapping automatically and estimate the proportion of invariable sites $($ GTRGAMMA + I)). Phylogenetic trees of CYC1 and $C Y C 3$ were midpoint rooted, while in $C Y C 2$ the Campanuloideae sequences were used as an outgroup to Lobelioideae sequences.

\section{Collection and dissection of floral tissues}

For expression studies, four Lobelioideae species were grown in the greenhouse at St. John's University, Queens, NY, USA: Lobelia erinus (Fig. 1H), Lo. siphilitica (Fig. 1G), Lo. polyphylla (Fig. 1I), and Lithotoma axillaris (Fig. 1F). Living collections are maintained at SJU greenhouse and herbarium specimens are deposited at NYBG. Flower buds were collected at three different developmental stages: small buds, medium buds, and large buds. The small buds of Lo. erinus were $2.5-4 \mathrm{~mm}$, medium buds were $5-6 \mathrm{~mm}$, and large buds were $7-8 \mathrm{~mm}$. For 
Lo. siphilitica, small buds were $5-6 \mathrm{~mm}$, medium buds were $8-12 \mathrm{~mm}$, and the large buds were $14-18 \mathrm{~mm}$. For Lo. polyphylla, small buds were 7-10 mm, medium buds were $15-20 \mathrm{~mm}$, and the large buds were $25-30 \mathrm{~mm}$. For Li. axillaris, small buds were $10-13 \mathrm{~mm}$, medium buds were $15-25 \mathrm{~mm}$, and the large buds were $25-35 \mathrm{~mm}$. Additionally, medium flower buds were dissected, after resupination, to separate the finally positioned dorsal, lateral, and ventral corolla lobes. Leaf tissue was separately collected as a control. All tissues were immediately frozen with liquid nitrogen and stored in a $-80{ }^{\circ} \mathrm{C}$ freezer until extraction. Roughly $20-30 \mathrm{mg}$ of tissue was collected for each RNA extraction. The exception was tissue from Lo. erinus flower buds, which are extremely small, with 3-4 mm medium size buds, so therefore, only roughly 15-20 mg was collected for RNA extraction in this species. Three biological replicates were collected for each type of tissue.

\section{Quantitative Real-Time PCR and statistical analysis}

Total RNA was extracted from plant tissues used for qRTPCR using the RNeasy Plant Mini Kit and RNase-free DNase kit (QIAGEN) according to the manufacturer's instructions and then stored at $-80{ }^{\circ} \mathrm{C}$. The concentrations and purities of all RNA samples were determined using a Thermo Scientific NanoDrop 2000 (Thermo Scientific, Waltham, MA). The qRT-PCR primers were designed in Geneious ${ }^{\circledR}$ Pro v.7.1.2 based on CamCYC2 gene sequences and ACTIN sequences collected in our study. Specific primer sets were designed for each species (Table 3). The qScript ${ }^{\mathrm{TM}}$ One-Step SYBR ${ }^{\circledR}$ Green qRTPCR Kit (QuantaBio) was used with manufacturer recommendations to investigate the expression patterns of CamCYC2A and CamCYC2B gene expression in the collected tissues from Lobelia erinus, Lo. siphilitica, Lithotoma axillaris, and Lo. polyphylla. Each type of tissue included three biological and two technical replicates. Samples were run on a Bio-Rad MyIQ Single Color RealTime RCR Detection System (Bio-Rad, Hercules, CA). The melting curve and threshold cycle $(\mathrm{Ct})$ values were analyzed by a modified $2^{-\Delta C}$ method [74]. Because all of the tissues used were from natural or wild-type plants, there was no "untreated control" to normalize the second delta as is standard in these methods. ANOVA and post hoc Tukey HSD were performed on the web site: https:// astatsa.com/OneWay_Anova_with_TukeyHSD/.

\section{Abbreviations}

CYC: CYCLOIDEA; TCP: Teosinte Branched1, CYCLOIDEA, proliferating cell factor; qPCR: Quantitative real-time polymerase chain reaction; RT-PCR: Reverse transcription polymerase chain reaction; ANOVA: Analysis of variance; HSD: Honest significant difference; Ct: Threshold cycle; CBS: Group of Lobelioideae including Centropogon, Burmeistera, and Siphocampylus.

\section{Acknowledgements}

The authors thank current and past lab members, especially Brent Berger, Jiahong Han, Vincent Ricigliano, and Jingbo Zhang for helpful discussion. The authors additionally thank SJU Departmental of Biological Sciences members, Ujwala Goasvi Khadtare, Ketan Patil, and Meenhaj Uddin for discussion and method advice.

\section{Authors' contributions}

JT and DGH designed the research. JT, FM, and ASZ conducted data sequence generation and analyzes. JT conducted the morphological dissections and qPCR experiments. JT conducted statistical analyses. JT, EBK, CWM, NC, and DGH provided interpretations of results. JT and DGH wrote the paper. JT, EBK, CWM, NC, FM, and ASZ, and DGH read, critiqued, and approved the final manuscript. All authors read and approved the final manuscript.

\section{Funding}

Not applicable.

\section{Availability of data and materials}

The datasets supporting the conclusions of this article are available in the TreeBase repository (https://www.treebase.org/treebase-web/login.jsp) and GenBank repository (XX-XX); not public until accepted).

\section{Declarations}

Ethics approval and consent to participate

Not applicable.

Consent for publication

Not applicable.

\section{Competing interests}

The authors declare no competing interests.

\section{Author details}

${ }^{1}$ Department of Biological Sciences, St. John's University, Jamaica, NY, USA. ${ }^{2}$ Department of Biology, Indiana University, Bloomington, IN, USA. ${ }^{3}$ Department of Botany, University of Hawai' $i$ at Mānoa, Honolulu, HI, USA. ${ }^{4}$ Florida Museum of Natural History, University of Florida, Gainesville, FL, USA.

Received: 12 August 2021 Accepted: 22 December 2021

Published online: 06 February 2022

\section{References}

1. Lammers TG. World checklist and bibliography of Campanulaceae. Richmond: Royal Botanic Gardens Kew; 2007.

2. Crowl AA, Miles NW, Visger CJ, Hansen K, Ayers T, Haberle R, et al. A global perspective on Campanulaceae: biogeographic, genomic, and floral evolution. Am J Bot. 2016;103(2):233-45.

3. Crowl AA, Mavrodiev E, Mansion G, Haberle R, Pistarino A, Kamari G, et al. Phylogeny of Campanuloideae (Campanulaceae) with emphasis on the utility of nuclear pentatricopeptide repeat (PPR) genes. PLOS ONE. 2014;9(4): e94199.

4. Knox EB, Muasya AM, Phillipson PB. The Lobeliaceae originated in southern Africa. In: Ghazanfar SA, Beentje H, editors. Taxonomy and ecology of african plants, their conservation and sustainable use: proceedings of the 17th AETFAT Congress, Addis Ababa, Ethiopia. Richmond: Royal Botanic Gardens Kew; 2006

5. Lagomarsino LP, Antonelli A, Muchhala N, Timmermann A, Mathews S, Davis CC. Phylogeny, classification, and fruit evolution of the speciesrich Neotropical bellflowers (Campanulaceae: Lobelioideae). Am J Bot. 2014;101(12):2097-112.

6. Knox EB, Muasya AM, Muchhala N. The predominantly South American clade of Lobeliaceae. Syst Bot. 2008;33(2):462-8.

7. Antonelli A. Higher level phylogeny and evolutionary trends in Campanulaceae subfam. Lobelioideae: molecular signal overshadows morphology. Mol Phylogen Evol. 2008;46:1-18. 
8. Antonelli A. Have giant lobelias evolved several times independently? Life form shifts and historical biogeography of the cosmopolitan and highly diverse subfamily Lobelioideae (Campanulaceae). BMC Biol. 2009;7:82.

9. Givnish TJ. Giant lobelias exemplify convergent evolution. BMC Biol. 2010;8:3.

10. Knox EB, Downie SR, Palmer JD. Chloroplast genome rearrangements and the evolution of giant lobelias from herbaceous ancestors. Mol Biol Evol. 1993;10(2):414-414.

11. Knox EB. The dynamic history of plastid genomes in the Campanulaceae sensu lato is unique among angiosperms. Proc Natl Acad Sci USA. 2014;111(30):11097-102.

12. Cellinese N, Smith S, Edwards E, Kim S-T, Haberle R, Avramakis E, et al. Historical biogeography of the endemic Campanulaceae of Crete. J Biogeogr. 2009;36:1253-69.

13. Linder HP. The evolution of African plant diversity. Front Ecol Evol. 2014;2:38.

14. Endress PK. Symmetry in flowers: diversity and evolution. Int J Plant Sci. 1999;160(S6):S3-23.

15. Neal PR, Dafni A, Giurfa M. Floral symmetry and its role in plant-pollinator systems: terminology, distribution, and hypotheses. Annu Rev Ecol Syst. 1998;29:345-73.

16. Sargent R. Floral symmetry affects speciation rate in angiosperms. Proc Biol Sci. 2004;271:603-8.

17. Donoghue M, Ree R, Baum D. Phylogeny and the evolution of flower symmetry in Asteridae. Trends Plant Sci. 1998;3(8):311-7.

18. Schultheis LM. Systematics of Downingia (Campanulaceae) based on molecular sequence data: implications for floral and chromosome evolution. Syst Bot. 2001;26(3):603-21.

19. Lammers TG, Hensold N. Chromosome numbers of Campanulaceae. II. The Lobelia tupa complex of Chile. Am J Bot. 1992;79(5):585-8.

20. Bukhari G, Zhang J, Stevens PF, Zhang W. Evolution of the process underlying floral zygomorphy development in pentapetalous angiosperms. Am J Bot. 2017:104(12):1846-56.

21. Luo D, Carpenter R, Vincent C, Copsey L, Coen E. Origin of floral asymmetry in Antirrhinum. Nature. 1996;383(6603):794-9.

22. Schwarz-Sommer Z, Huijser P, Nacken W, Saedler H, Sommer H. Genetic control of flower development by homeotic genes in Antirrhinum majus. Science. 1990;250(4983):931-6.

23. Corley SB, Carpenter R, Copsey L, Coen E. Floral asymmetry involves an interplay between TCP and MYB transcription factors in Antirrhinum. Proc Natl Acad Sci USA. 2005;102(14):5068-73.

24. Cubas P. Floral zygomorphy, the recurring evolution of a successful trait. BioEssays. 2004;26(11):1175-84.

25. Jabbour F, Nadot S, Damerval C. Evolution of floral symmetry: a state of the art. C R Biol. 2009;332(2-3):219-31.

26. Preston JC, Kost MA, Hileman LC. Conservation and diversification of the symmetry developmental program among close relatives of snapdragon with divergent floral morphologies. New Phytol. 2009;182(3):751-62.

27. Cubas P. Role of TCP genes in the evolution of key morphological characters in Angiosperms. In Developmental Genetics and Plant Evolution; Eds Cronk QCB, Bateman RM, Hawkins JA; London: Taylor and Francis; 2002. p. 247-66.

28. Luo D, Carpenter R, Copsey L, Vincent C, Clark J, Coen E. Control of organ asymmetry in flowers of Antirrhinum. Cell. 1999;99(4):367-76.

29. Bello MA, Cubas P, Álvarez I, Sanjuanbenito G, Fuertes-Aguilar J. Evolution and expression patterns of CYC/TB1 genes in Anacyclus: phylogenetic insights for floral symmetry genes in Asteraceae. Front Plant Sci. 2017;8:589.

30. Berger BA, Ricigliano VA, Savriama Y, Lim A, Thompson V, Howarth DG. Geometric morphometrics reveals shifts in flower shape symmetry and size following gene knockdown of CYCLOIDEA and ANTHOCYANIDIN SYNTHASE. BMC Plant Biol. 2017;17:205.

31. Chapman MA, Tang S, Draeger D, Nambeesan S, Shaffer H, Barb JG, et al. Genetic analysis of floral symmetry in Van Gogh's sunflowers reveals independent recruitment of CYCLOIDEA genes in the Asteraceae. PLoS Genet. 2012;8(3): e1002628.

32. Chen J, Shen CZ, Guo YP, Rao GY. Patterning the Asteraceae capitulum: duplications and differential expression of the flower symmetry CYC2Like genes. Front Plant Sci. 2018;9:551.
33. Citerne HL, Luo D, Pennington RT, Coen E, Cronk QCB. A Phylogenomic investigation of CYCLOIDEA-like TCP genes in the Leguminosae. Plant Physiol. 2003;131(3):1042-53.

34. Citerne HL, Möller M, Cronk QCB. Diversity of cycloidea-like genes in Gesneriaceae in relation to floral symmetry. Ann Bot. 2000;86(1):167-76.

35. Claßen-Bockhoff R, Ruonala R, Bull-Hereñu K, Marchant N, Albert V. The unique pseudanthium of Actinodium (Myrtaceae) — morphological reinvestigation and possible regulation by CYCLOIDEA-like genes. EvoDevo. 2013;4:8

36. Howarth DG, Martins T, Chimney E, Donoghue MJ. Diversification of CYCLOIDEA expression in the evolution of bilateral flower symmetry in Caprifoliaceae and Lonicera (Dipsacales). Ann Bot. 2011;107(9):1521-32

37. Tähtiharju S, Rijpkema AS, Vetterli A, Albert VA, Teeri TH, Elomaa P. Evolution and diversification of the CYC/TB1 gene family in Asteraceae-a comparative study in Gerbera (Mutisieae) and sunflower (Heliantheae). Mol Biol Evol. 2012;29(4):1155-66.

38. Xu S, Luo Y, Cai Z, Cao X, Hu X, Yang J, et al. Functional diversity of CYCLOIDEA-like TCP genes in the control of zygomorphic flower development in Lotus japonicus. J Integr Plant Biol. 2013;55(3):221-31.

39. Hileman LC. Trends in flower symmetry evolution revealed through phylogenetic and developmental genetic advances. Philos Trans R Soc Lond B Biol Sci. 2014;369:20130348.

40. Berger BA, Thompson V, Lim A, Ricigliano VA, Howarth DG. Elaboration of bilateral symmetry across Knautia macedonica capitula related to changes in ventral petal expression of CYCLOIDEA-like genes. EvoDevo. 2016;7:8.

41. Howarth DG, Donoghue MJ. Phylogenetic analysis of the "ECE" (CYC (TB1) clade reveals duplications predating the core eudicots. Proc Natl Acad Sci USA. 2006;103(24):9101-6.

42. Muhr M, Prüfer N, Paulat M, Teichmann T. Knockdown of strigolactone biosynthesis genes in Populus affects BRANCHED1 expression and shoot architecture. New Phytol. 2016;212(3):613-26.

43. Finlayson SA. Arabidopsis TEOSINTE BRANCHED1-LIKE 1 regulates axillary bud outgrowth and is homologous to monocot TEOSINTE BRANCHED1. Plant Cell Physiol. 2007:48(5):667-77.

44. Aguilar-Martínez JA, Poza-Carrión C, Cubas P. Arabidopsis BRANCHED1 acts as an integrator of branching signals within axillary buds. Plant Cell. 2007;19(2):458-72.

45. Chapman MA, Leebens-Mack JH, Burke JM. Positive selection and expression divergence following gene duplication in the sunflower CYCLOIDEA gene family. Mol Biol Evol. 2008;25(7):1260-73.

46. Knox EB, Li C. The East Asian origin of the giant lobelias. Am J Bot. 2017;104(6):924-38.

47. Knox EB, Palmer JD. Chloroplast DNA evidence on the origin and radiation of the giant lobelias in eastern Africa. Syst Bot. 1998;23(2):109-49.

48. Lammers TG. Chromosome numbers of Campanulaceae. III. Review and integration of data for subfamily Lobelioideae. Am J Bot. 1993. https://doi.org/10.1002/j.1537-2197.1993.tb15237.x.

49. Knox EB, Kowal R. Chromosome numbers of the East African giant senecios and giant lobelias and their evolutionary significance. Am J Bot. 1993;80:847-53.

50. Specht $C D$, Howarth DG. Adaptation in flower form: a comparative evodevo approach. New Phytol. 2015;206(1):74-90.

51. Wang Z, Luo Y, Li X, Wang L, Xu S, Yang J, et al. Genetic control of floral zygomorphy in pea (Pisum sativum L.). Proc Natl Acad Sci USA. 2008;105(30):10414-9.

52. Feng X, Zhao Z, Tian Z, Xu S, Luo Y, Cai Z, et al. Control of petal shape and floral zygomorphy in Lotus japonicus. Proc Natl Acad Sci USA. 2006;103(13):4970-5.

53. Zhou X-R, Wang Y-Z, Smith JF, Chen R. Altered expression patterns of TCP and MYB genes relating to the floral developmental transition from initial zygomorphy to actinomorphy in Bournea (Gesneriaceae). New Phytol. 2008;178(3):532-43.

54. Pang H-B, Sun Q-W, He S-Z, Wang Y-Z. Expression pattern of CYC-like genes relating to a dorsalized actinomorphic flower in Tengia (Gesneriaceae). J Syst Evol. 2010;48(5):309-17.

55. Preston JC, Martinez CC, Hileman LC. Gradual disintegration of the floral symmetry gene network is implicated in the evolution of a wind-pollination syndrome. Proc Natl Acad Sci USA. 2011;108(6):2343-8. 
56. Zhang W, Kramer EM, Davis CC. Floral symmetry genes and the origin and maintenance of zygomorphy in a plant-pollinator mutualism. Proc Natl Acad Sci USA. 2010;107(14):6388-93.

57. Zhang W, Kramer EM, Davis CC. Similar genetic mechanisms underlie the parallel evolution of floral phenotypes. PLoS ONE. 2012;7(4): e36033.

58. Zhang W, Steinmann V, Nikolov L, Kramer E, Davis C. Divergent genetic mechanisms underlie reversals to radial floral symmetry from diverse zygomorphic flowered ancestors. Front Plant Sci. 2013;4:302.

59. Carlson SE, Howarth DG, Donoghue MJ. Diversification of CYCLOIDEAlike genes in Dipsacaceae (Dipsacales): implications for the evolution of capitulum inflorescences. BMC Evol Biol. 2011;11:325.

60. Howarth DG, Donoghue MJ. Duplications in CYC-like genes from Dipsacales correlate with floral form. Int J Plant Sci. 2005;166(3):357-70.

61. Song C-F, Lin Q-B, Liang R-H, Wang Y-Z. Expressions of ECE-CYC2 clade genes relating to abortion of both dorsal and ventral stamens in Opithandra (Gesneriaceae). BMC Evol Biol. 2009;9(1):244.

62. Zhao Z, Hu J, Chen S, Luo Z, Luo D, Wen J, et al. Evolution of CYCLOIDEAlike genes in fabales: insights into duplication patterns and the control of floral symmetry. Mol Phylogen Evol. 2019;132:81-9.

63. Muhr M, Paulat M, Awwanah M, Brinkkötter M, Teichmann T. CRISPR/Cas9mediated knockout of Populus BRANCHED1 and BRANCHED2 orthologs reveals a major function in bud outgrowth control. Tree Physiol. 2018;38(10):1588-97.

64. Eichler AW. Blüthendiagramme construirt und erläutert [flower diagrams constructed and explained], vol. 2. Leipig: Engelmann; 1878. p. 1878.

65. Schönland S. Notes on Cyphia volubilis, Willd. Trans South Afri Philos Soc. 1889;6(1):44-51.

66. Lammers TG. Flowering plants, Eudicots, Asterales. In: Kadereit JW, Jeffrey C, editors. Campanulaceae. The families and genera of vascular plants, vol. 8. Heidelberg: Springer; 2007. p. 27-56.

67. Leins P, Erbar C. Floral morphological studies in the South African Cyphia stenopetala Diels (Cyphiaceae). Int J Plant Sci. 2005;166(2):207-17.

68. Martín-Trillo M, Cubas P.TCP genes: a family snapshot ten years later. Trends Plant Sci. 2010;15(1):31-9.

69. Stace HM, James SH. Another perspective on cytoevolution in Lobelioideae (Campanulaceae). Am J Bot. 1996;83(10):1356-64.

70. Walsh NG, Albrecht DE, Knox EB. Notes and new taxa in Lobelia sect. Holopogon (Campanulaceae: Lobelioideae). Muelleria. 2010;28(2):146-62.

71. Chen L-Y, Wang Q-F, Renner SS. East Asian Lobelioideae and ancient divergence of a giant rosette Lobelia in Himalayan Bhutan. Taxon. 2016;65(2):293-304.

72. Rosenthal A, Coutelle O, Craxton M. Large-scale production of DNA sequencing templates by microtitre format PCR. Nucleic Acids Res. 1993;21(1):173-4.

73. Mesquite: a modular system for evolutionary analysis, Version 3.61.

74. Livak KJ, Schmittgen TD. Analysis of relative gene expression data using real-time quantitative PCR and the $2-\triangle \triangle C T$ method. Methods. 2001;25(4):402-8.

75. Randell RA, Morden CW. Hawaiian plant DNA library II: endemic, indigenous, and introduced species. Pac Sci. 1999;53(4):401-17.

76. Morden CW, Caraway V, Motley TJ. Development of a DNA Library for native Hawaiian Plants. Pac Sci. 1996;50(3):324-35.

\section{Publisher's Note}

Springer Nature remains neutral with regard to jurisdictional claims in published maps and institutional affiliations.

Ready to submit your research? Choose BMC and benefit from:

- fast, convenient online submission

- thorough peer review by experienced researchers in your field

- rapid publication on acceptance

- support for research data, including large and complex data types

- gold Open Access which fosters wider collaboration and increased citations

- maximum visibility for your research: over $100 \mathrm{M}$ website views per year

At BMC, research is always in progress.

Learn more biomedcentral.com/submissions 